\title{
Route to Highly Substituted Pyridines
}

Justin A. Hilf, Michael S. Holzwarth, and Scott D. Rychnovsky*

Department of Chemistry, University of California, Irvine, 1102 Natural Sciences II, Irvine, CA 92697, United States

Email address: srychnov@uci.edu

Supporting Information

Table of Contents

Proton and Carbon Spectra

S2-S46 

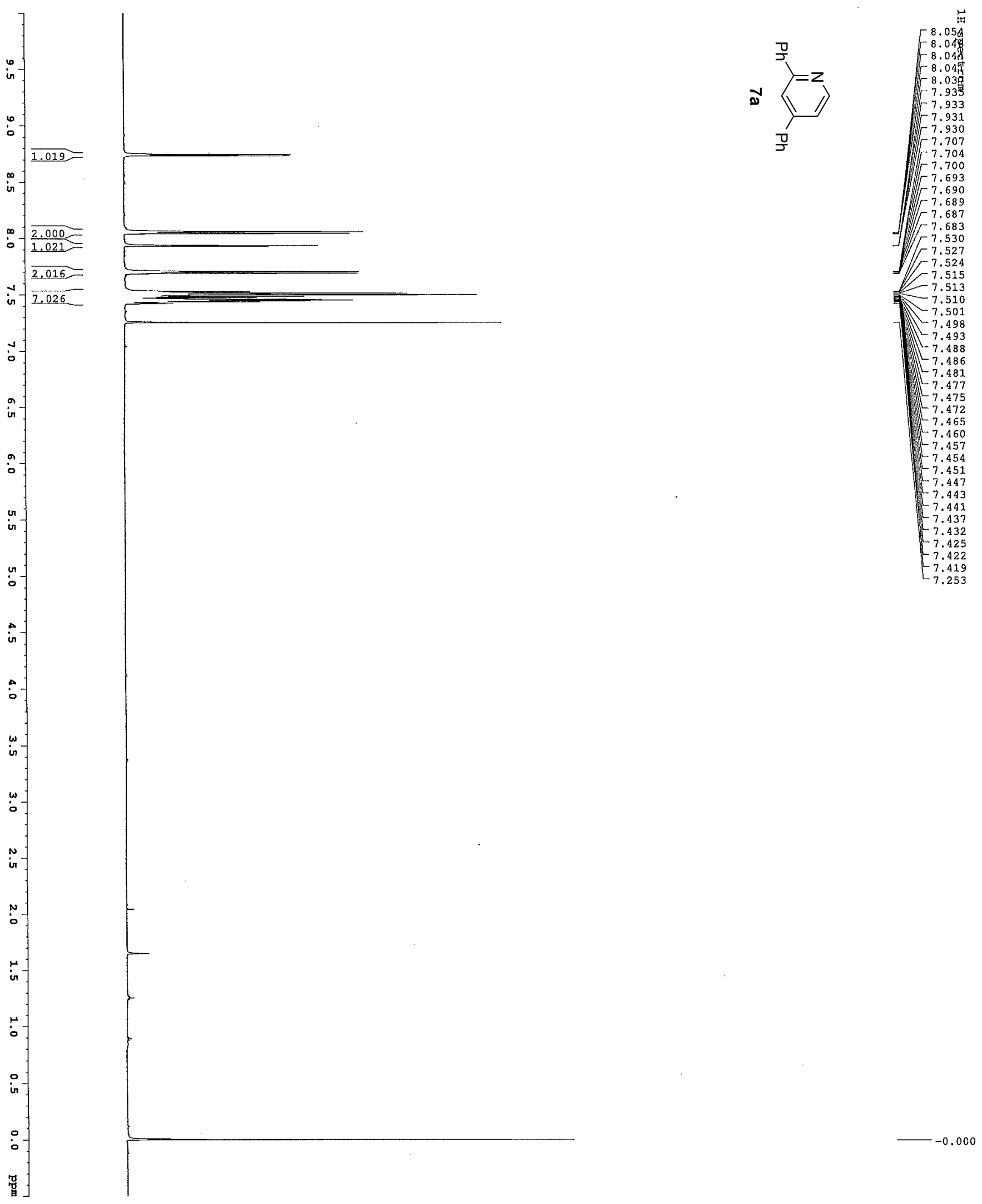


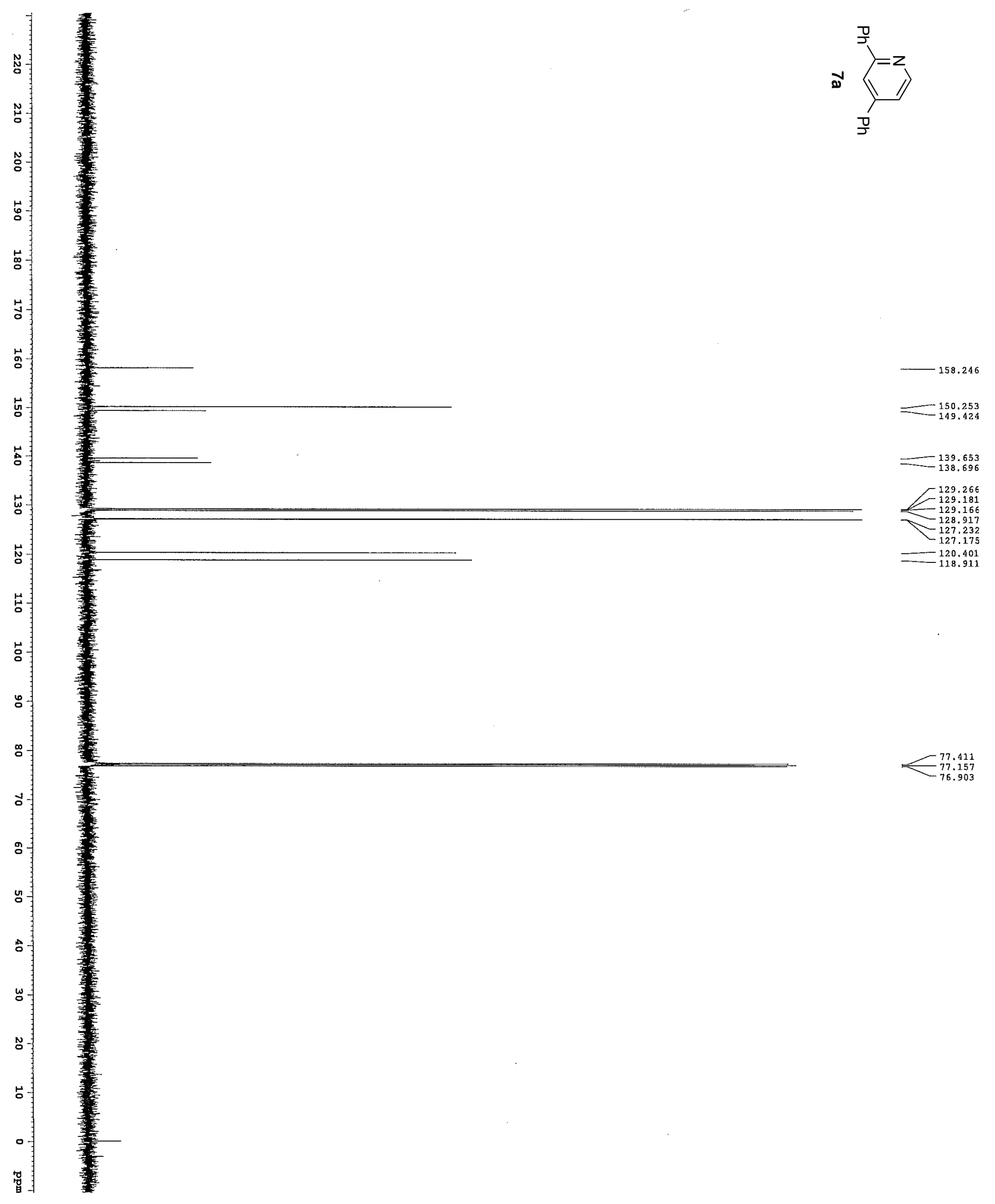




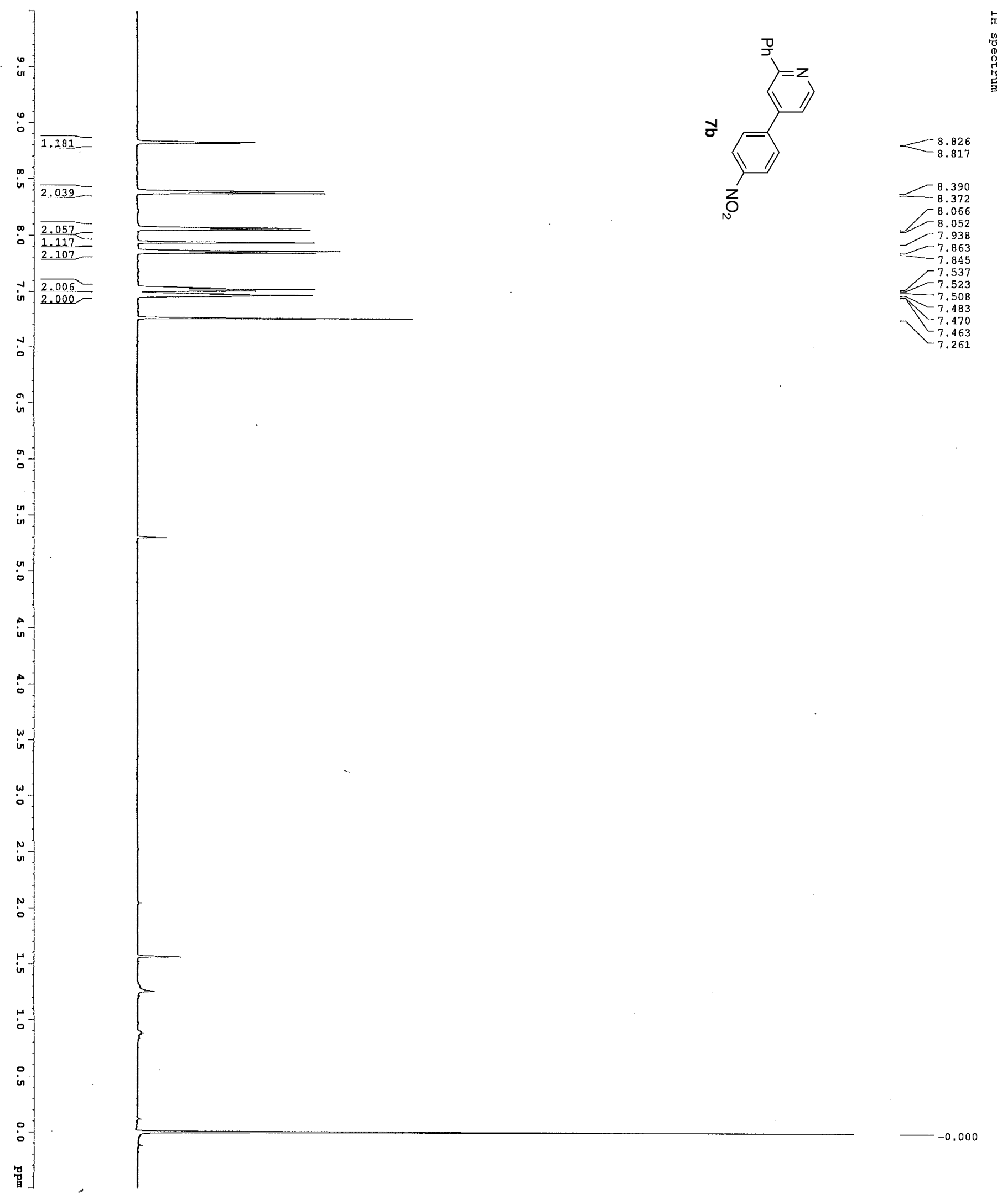



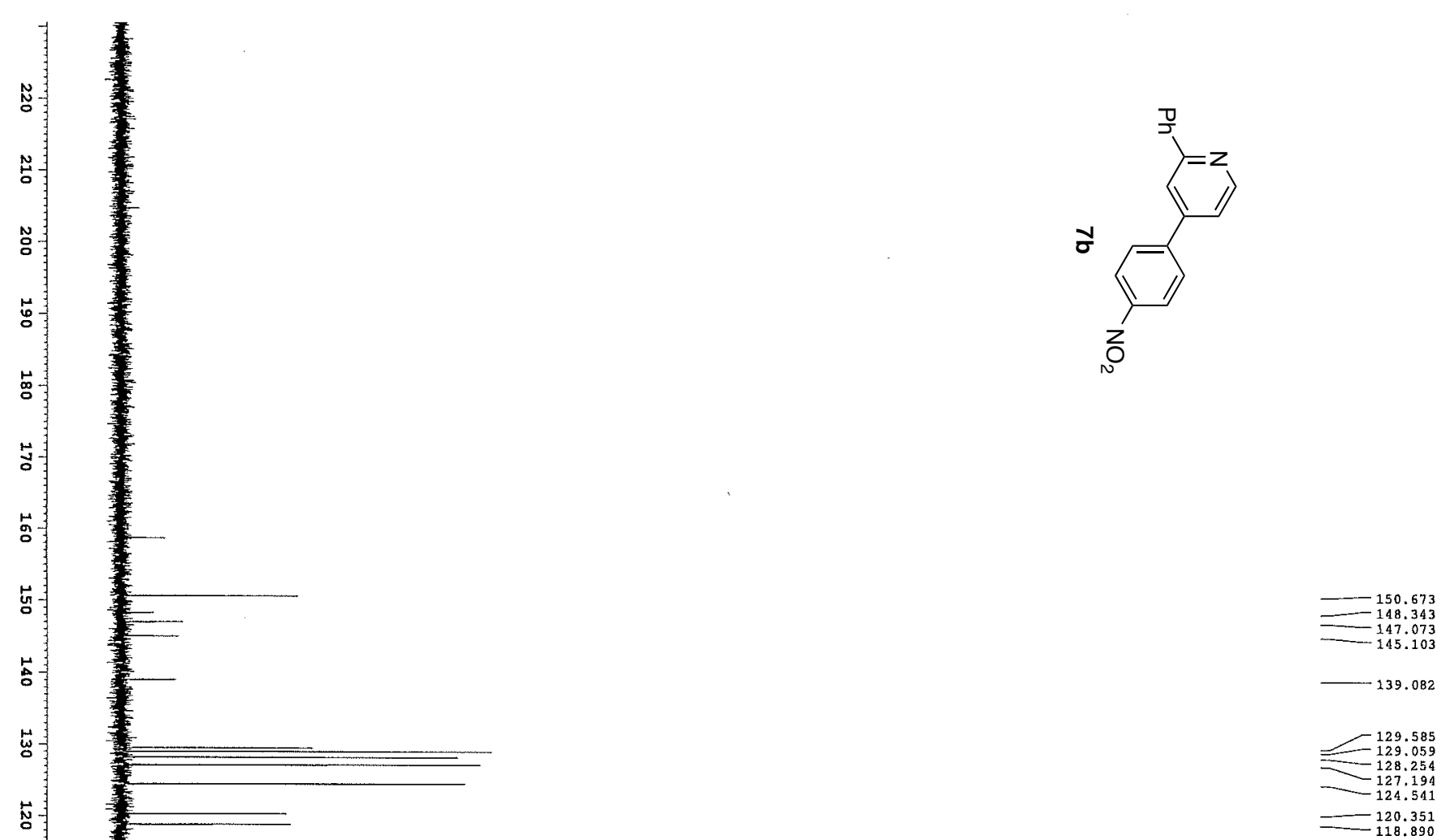

$<_{\substack{77.112 \\ 76.905}}^{71.12}$ 


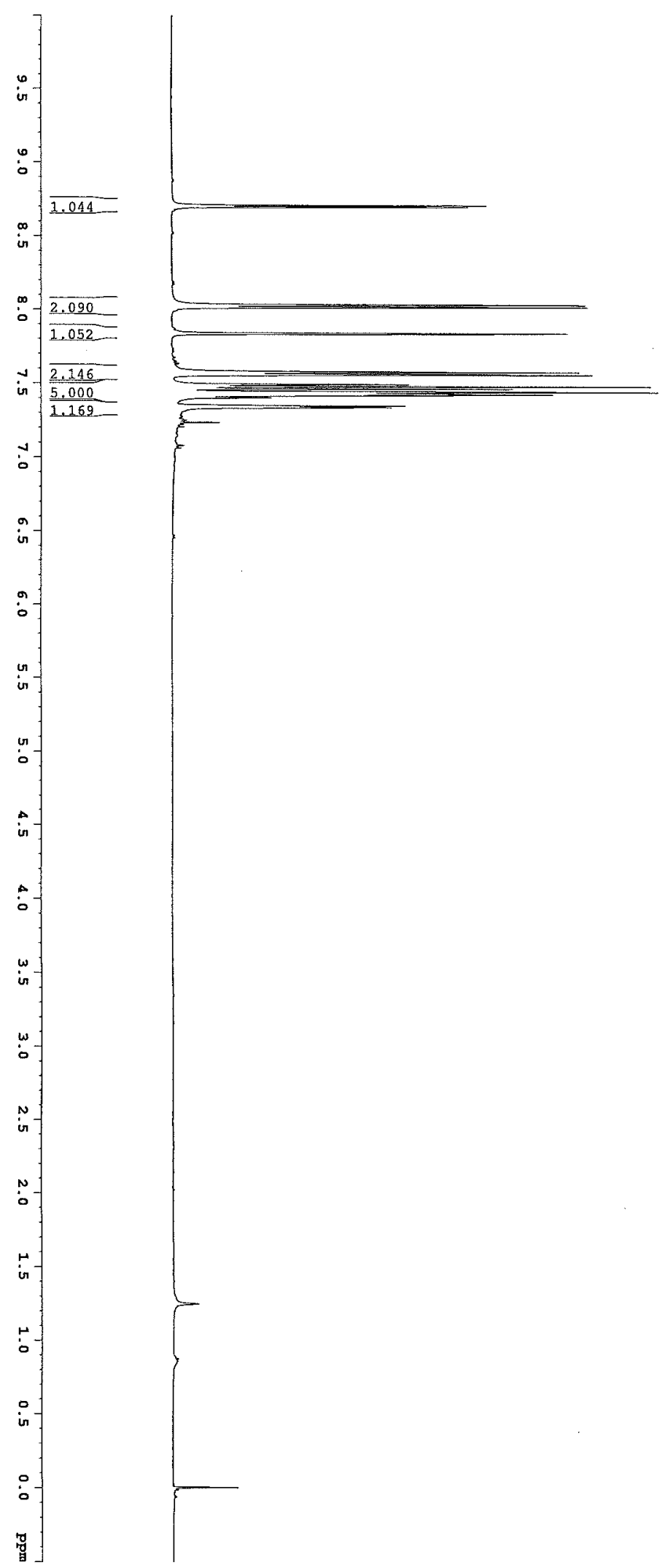<smiles>Cc1cccc(-c2ccc(O)cc2)c1</smiles>

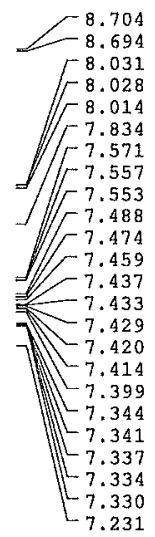



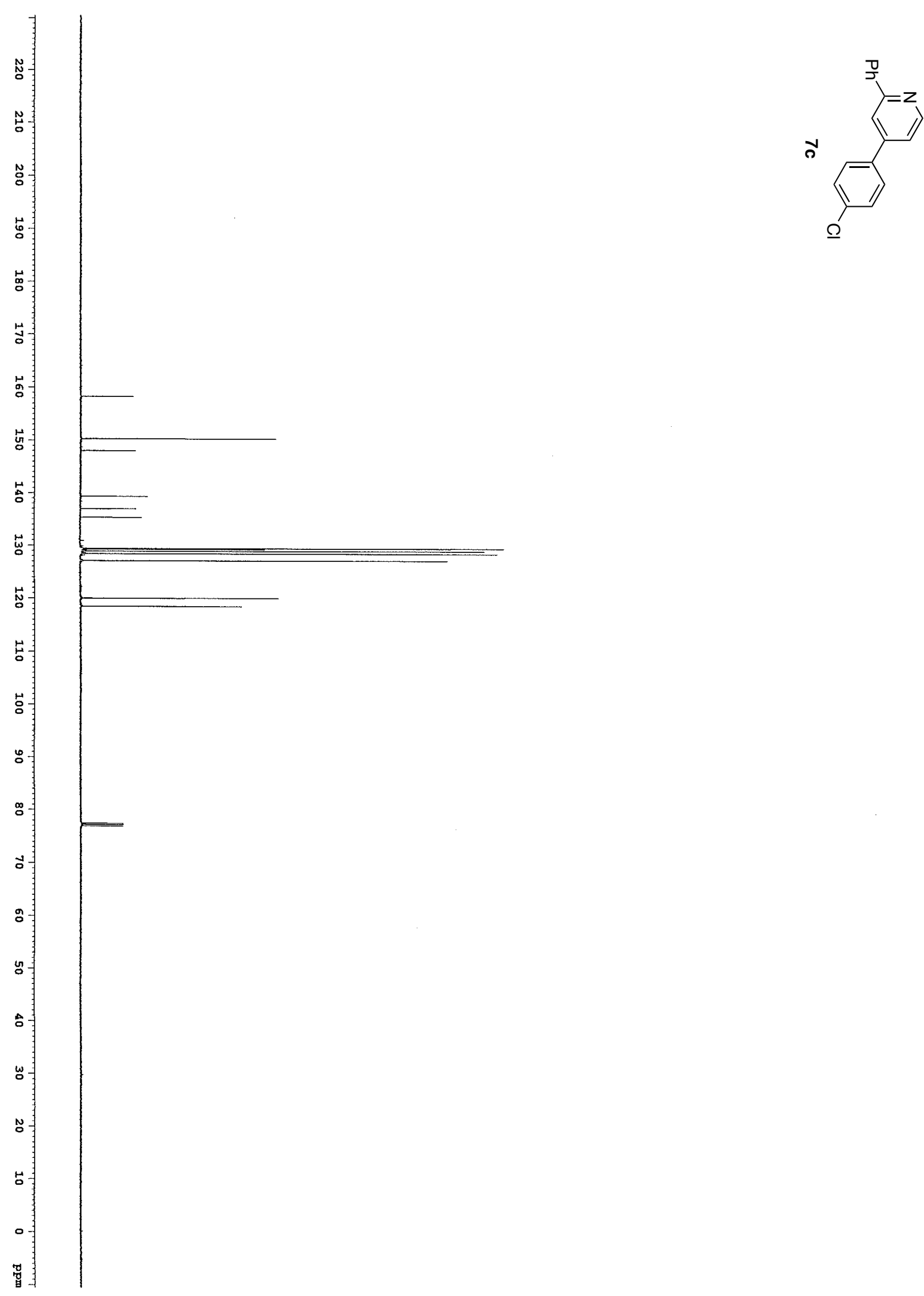

$-158.252$
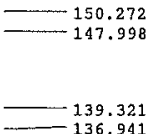

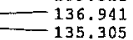

129.372
-129.217

$-128.380$

$=\quad \begin{array}{r}119.998 \\ -118.452\end{array}$

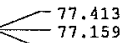

$-77.159$ 

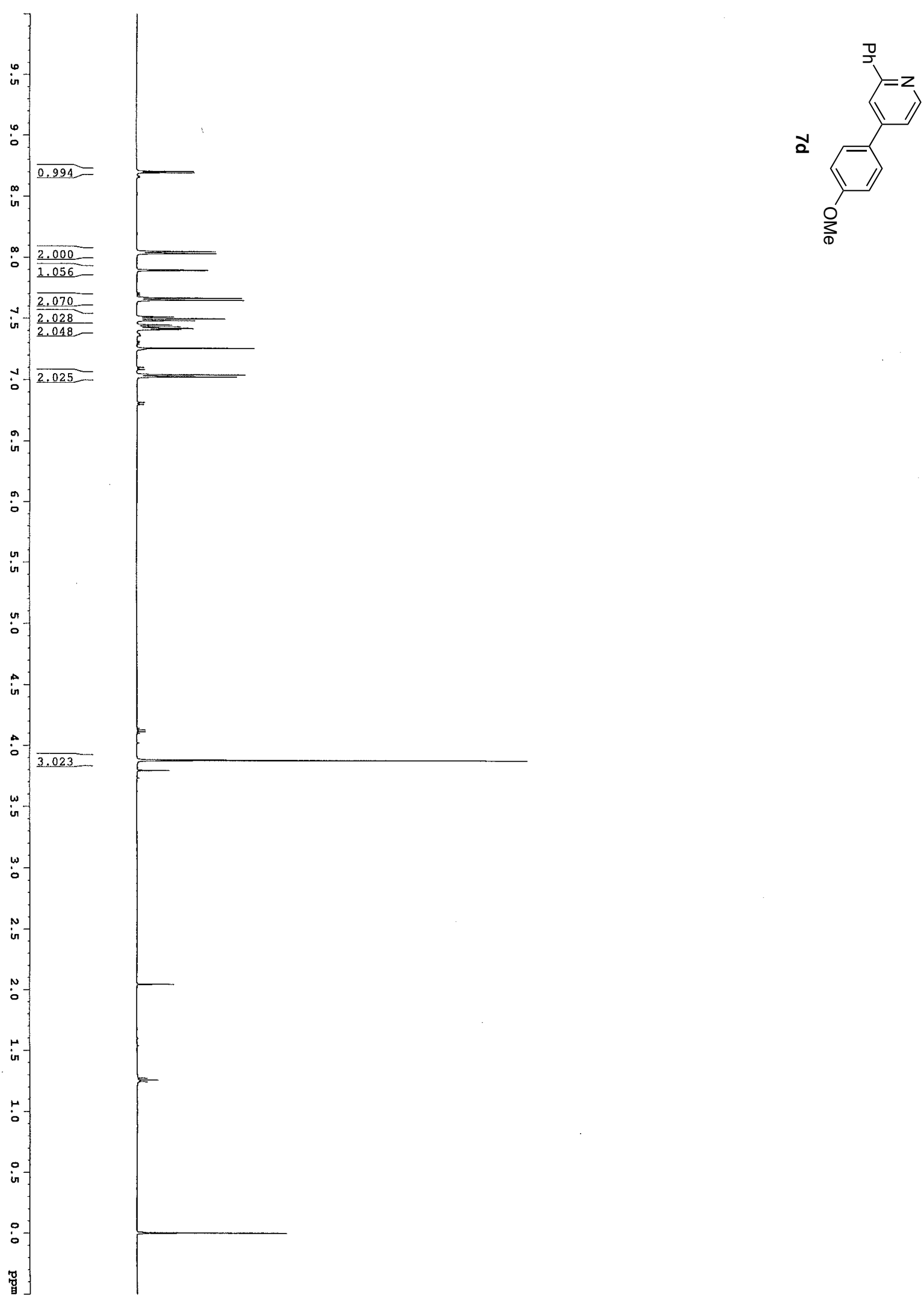

7.420

]. -7.416

$\mathbb{2} 7.406$

7.040
7.036

7.036
-7.023 


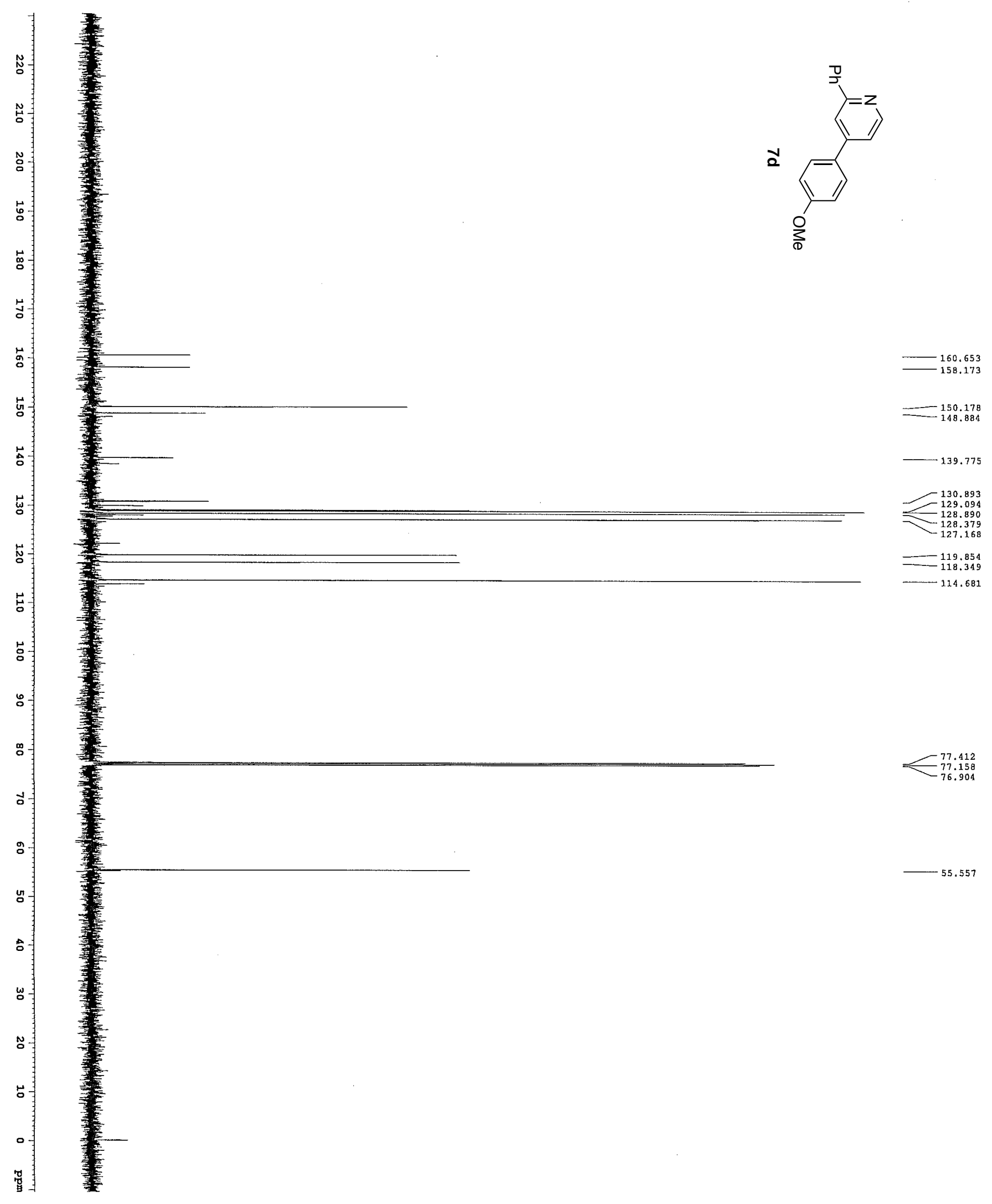




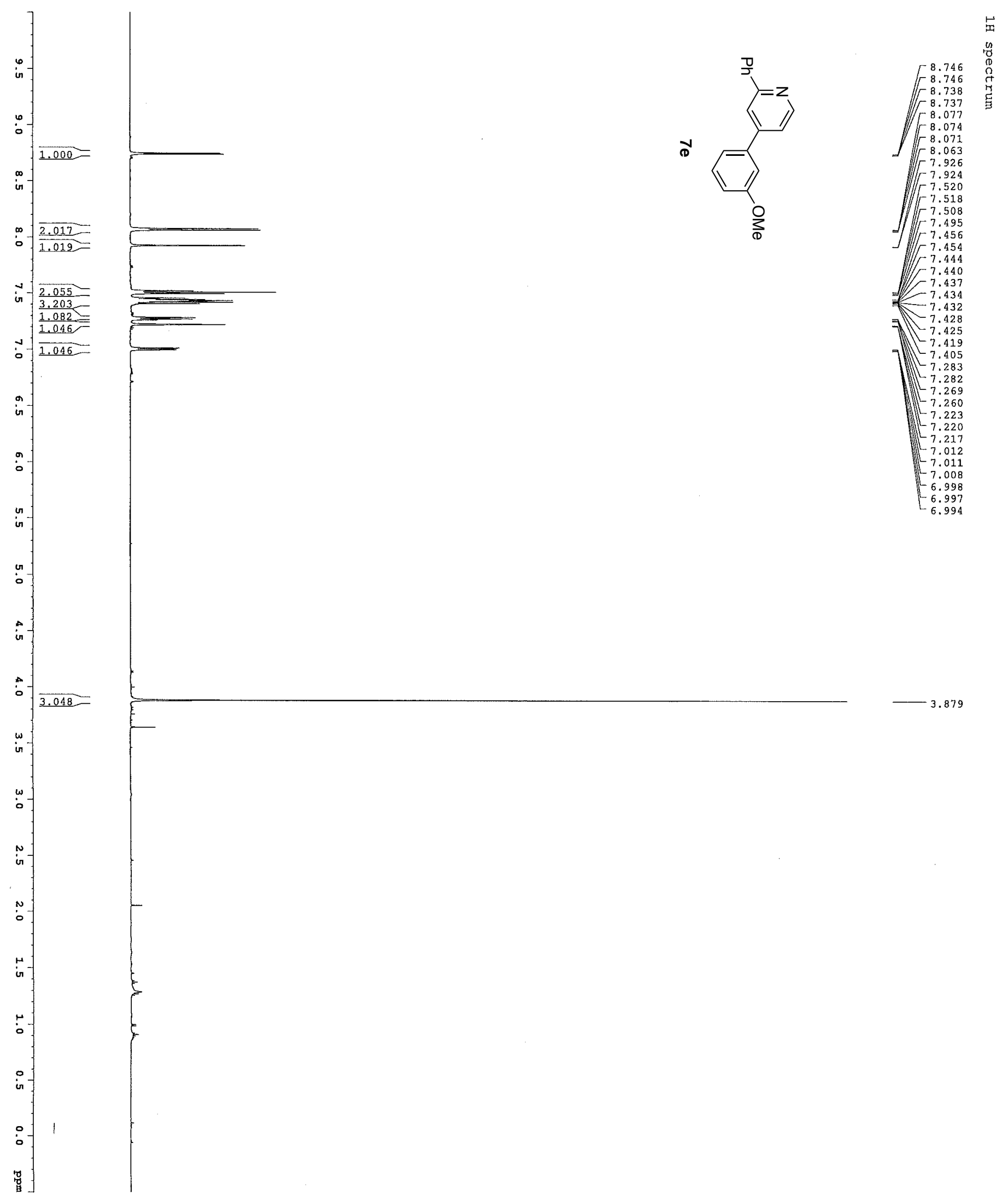



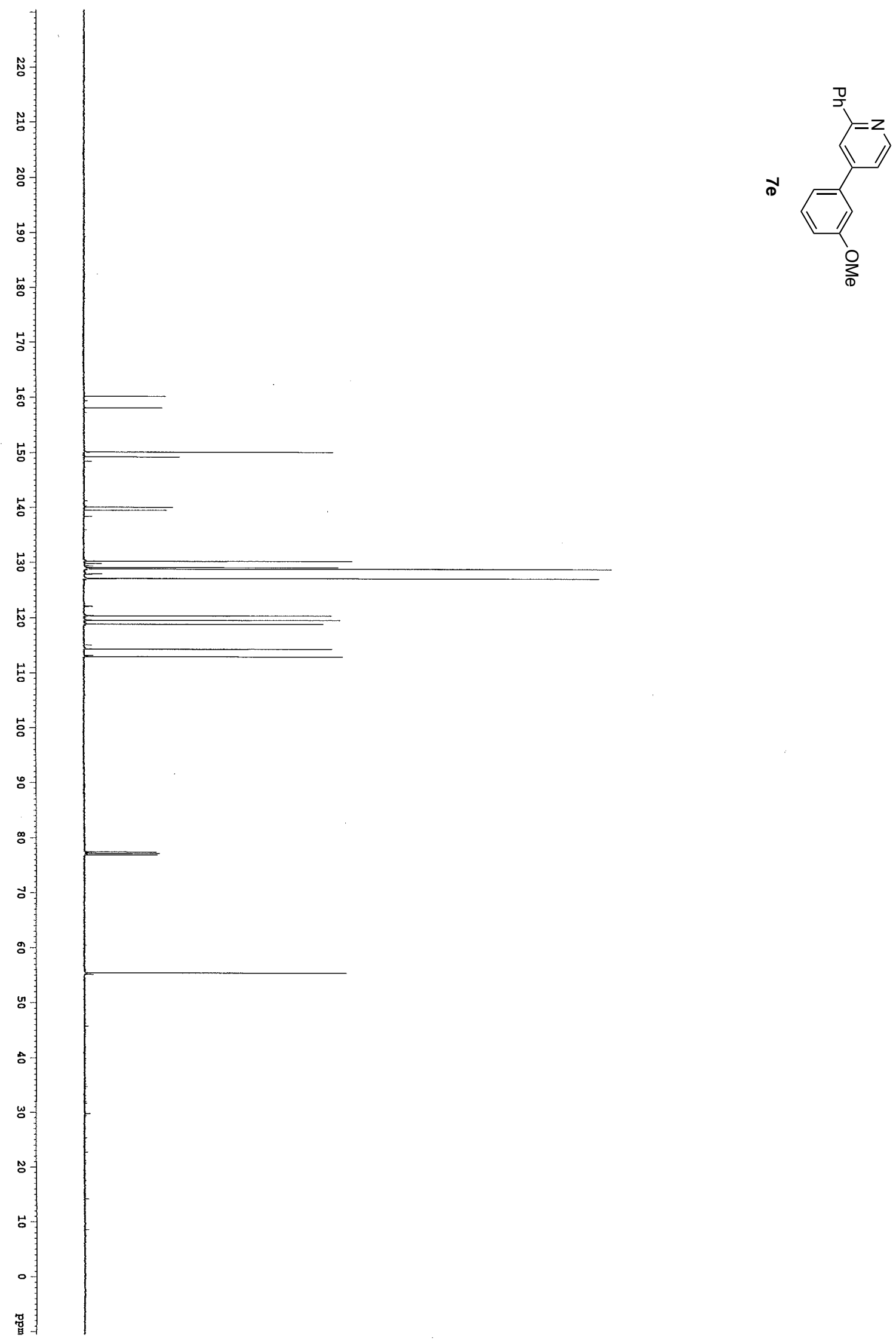

$-130.245$ -
-
-128.838
-127.109

$\begin{array}{r}-120.366 \\ \hline-119.546 \\ \hline\end{array}$

=- 114.322

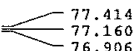

$-55.432$ 

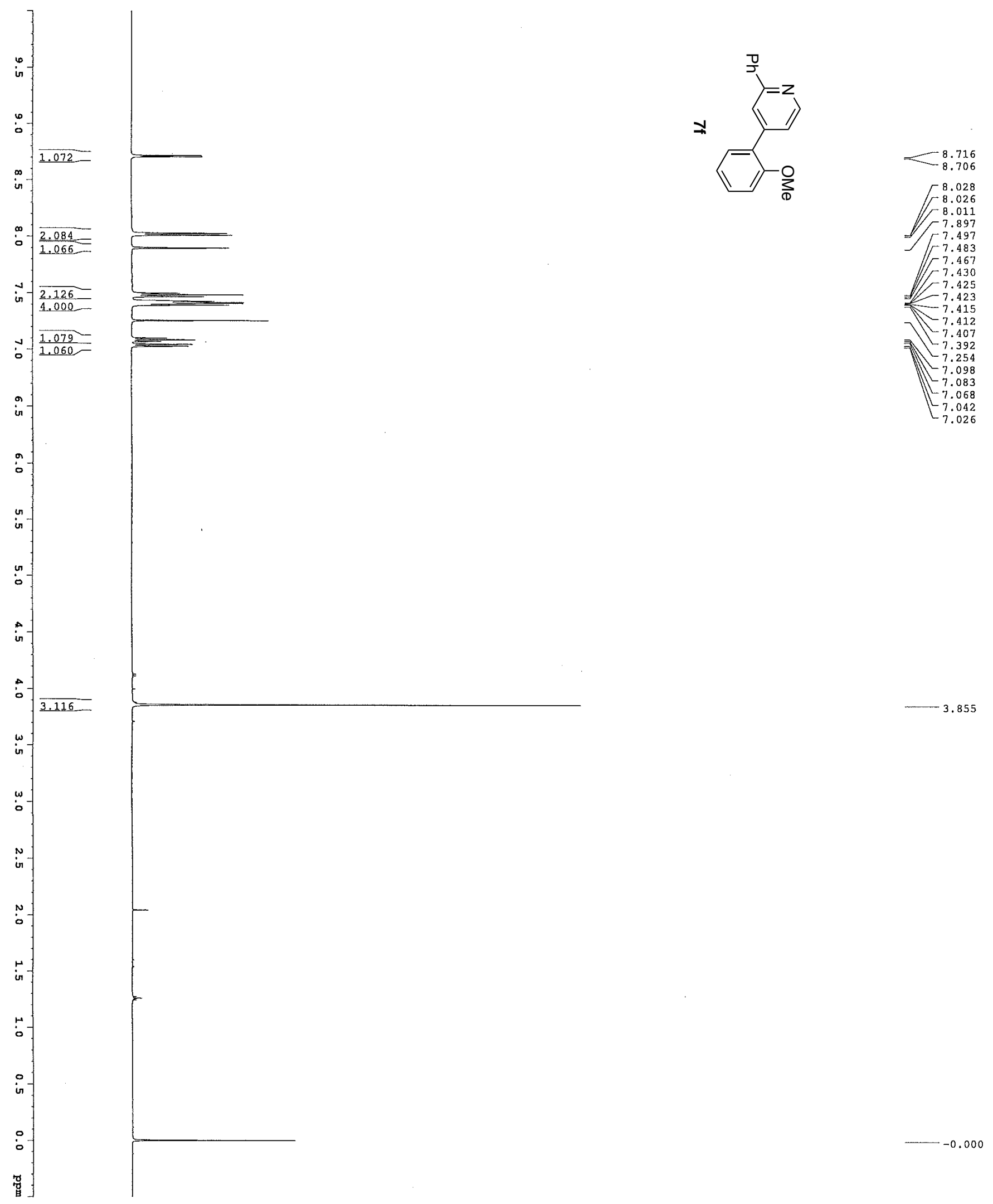

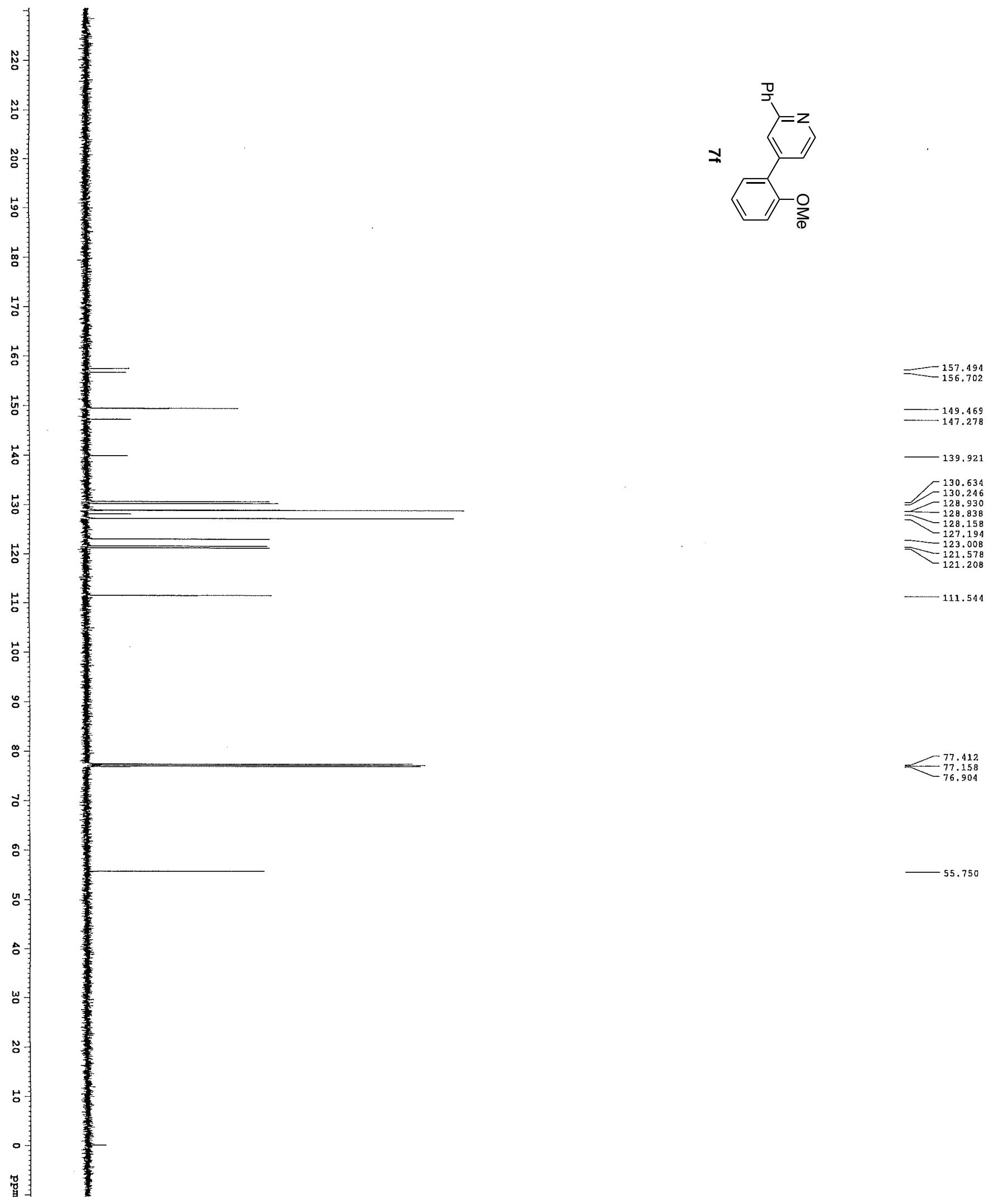

$-55.750$ 


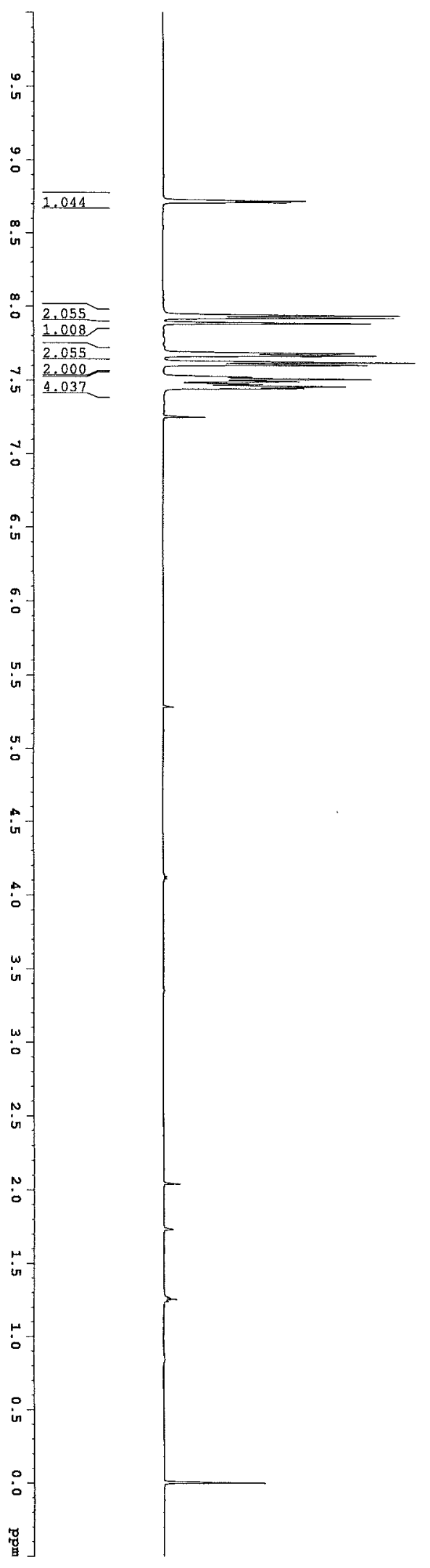<smiles>[B]c1ccc(-c2ccc(Br)cc2)cc1</smiles> 

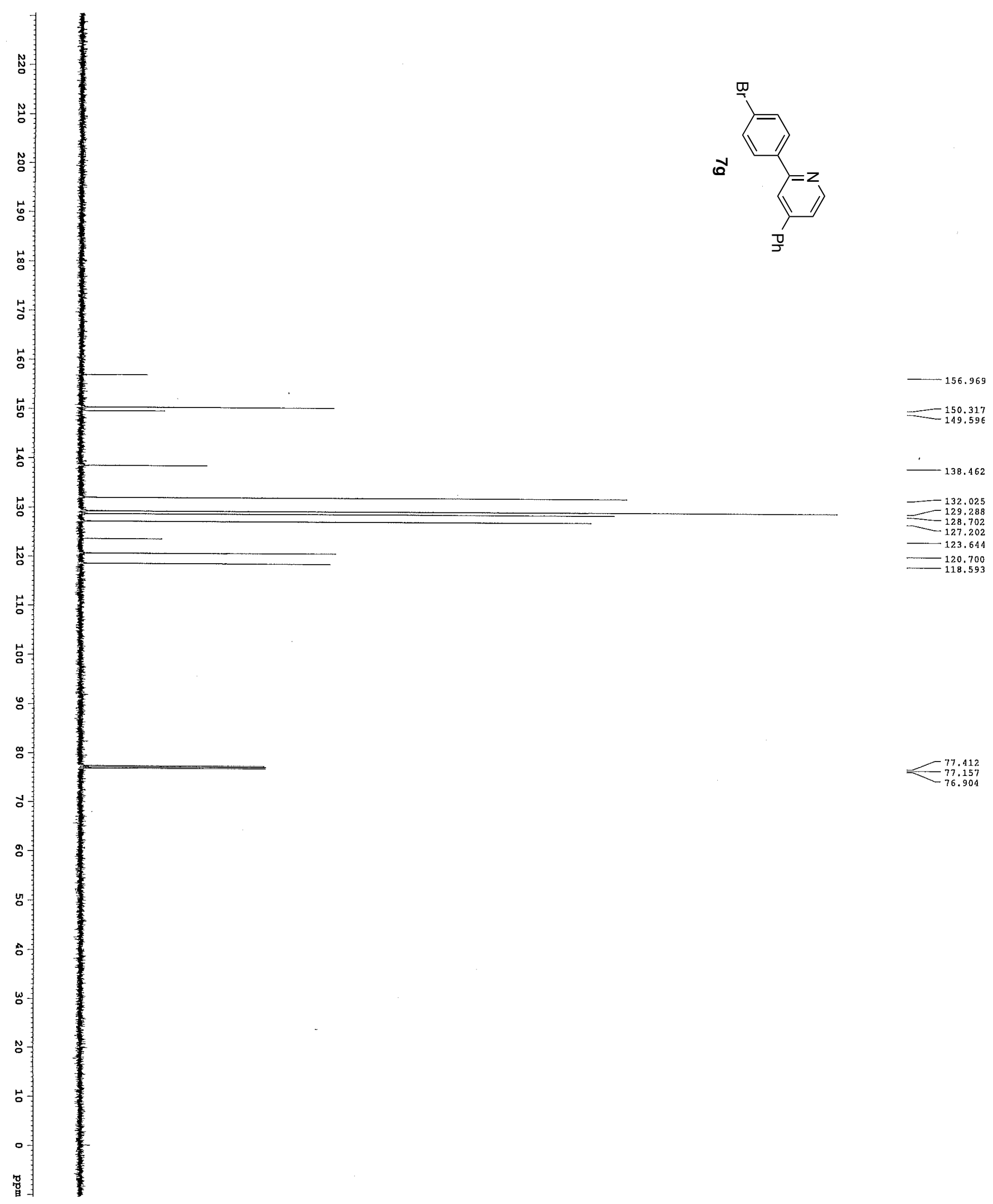

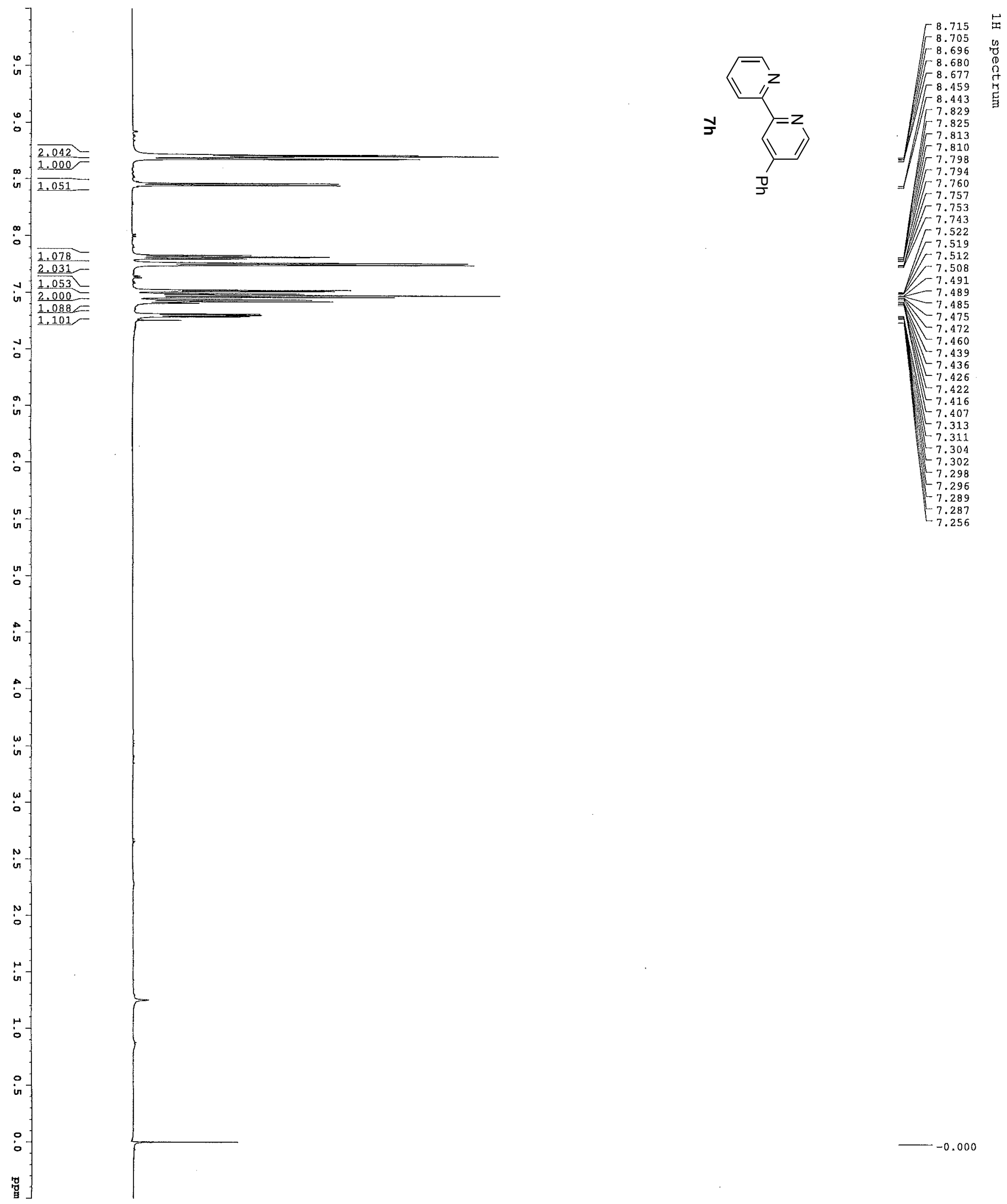

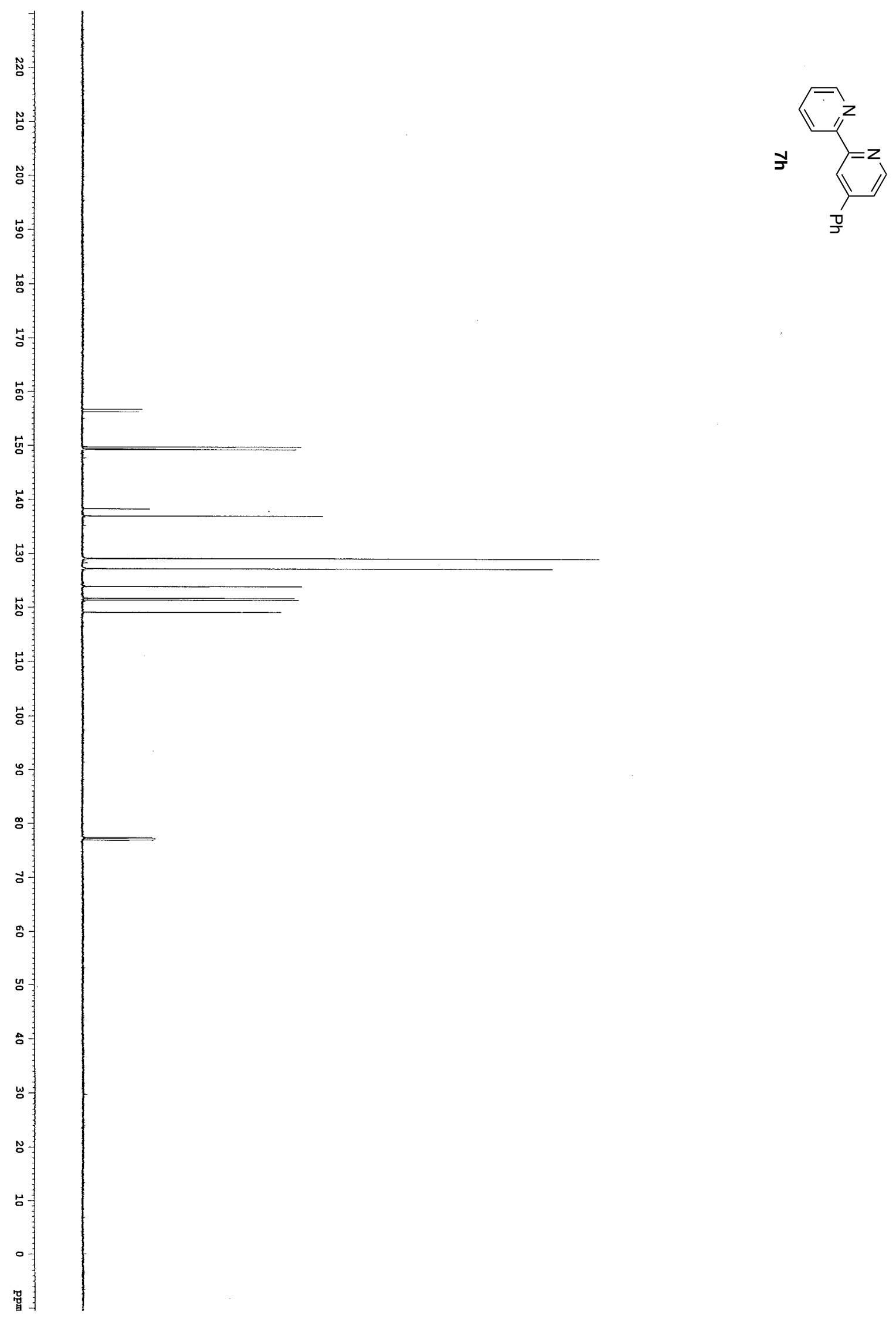

$=\begin{array}{r}1.56 .702 \\ -156.198 \\ \hline\end{array}$ 149.722
-149.737
-149.245

$=\quad \begin{array}{r}138.324 \\ 137.003\end{array}$

$\begin{array}{r}129.116 \\ \leq \quad 129.087 \\ \hline \quad 127.214 \\ \hline\end{array}$ - 123.865 $\begin{array}{r}121.681 \\ 119.091 \\ -\quad 126 \\ \hline\end{array}$ 

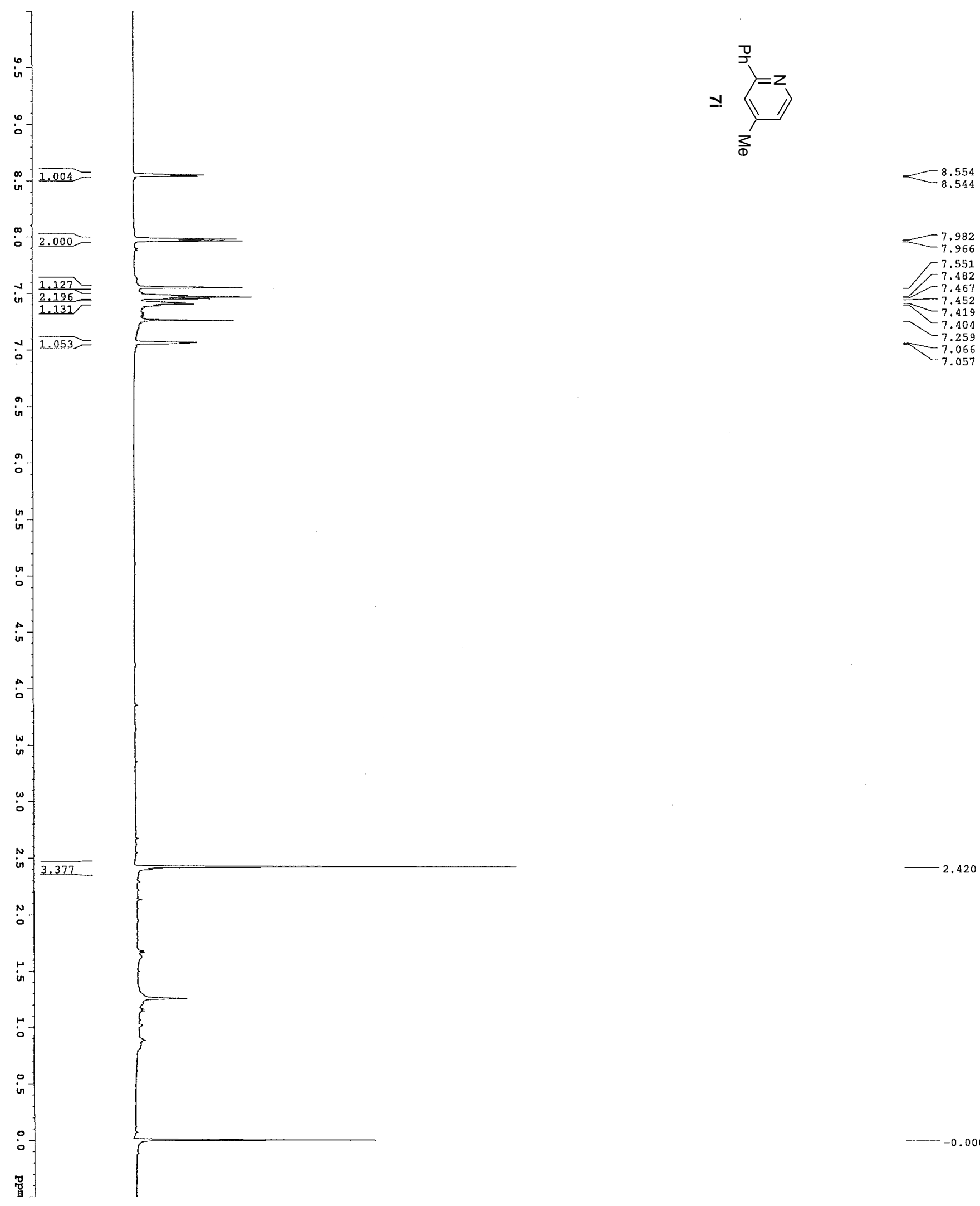


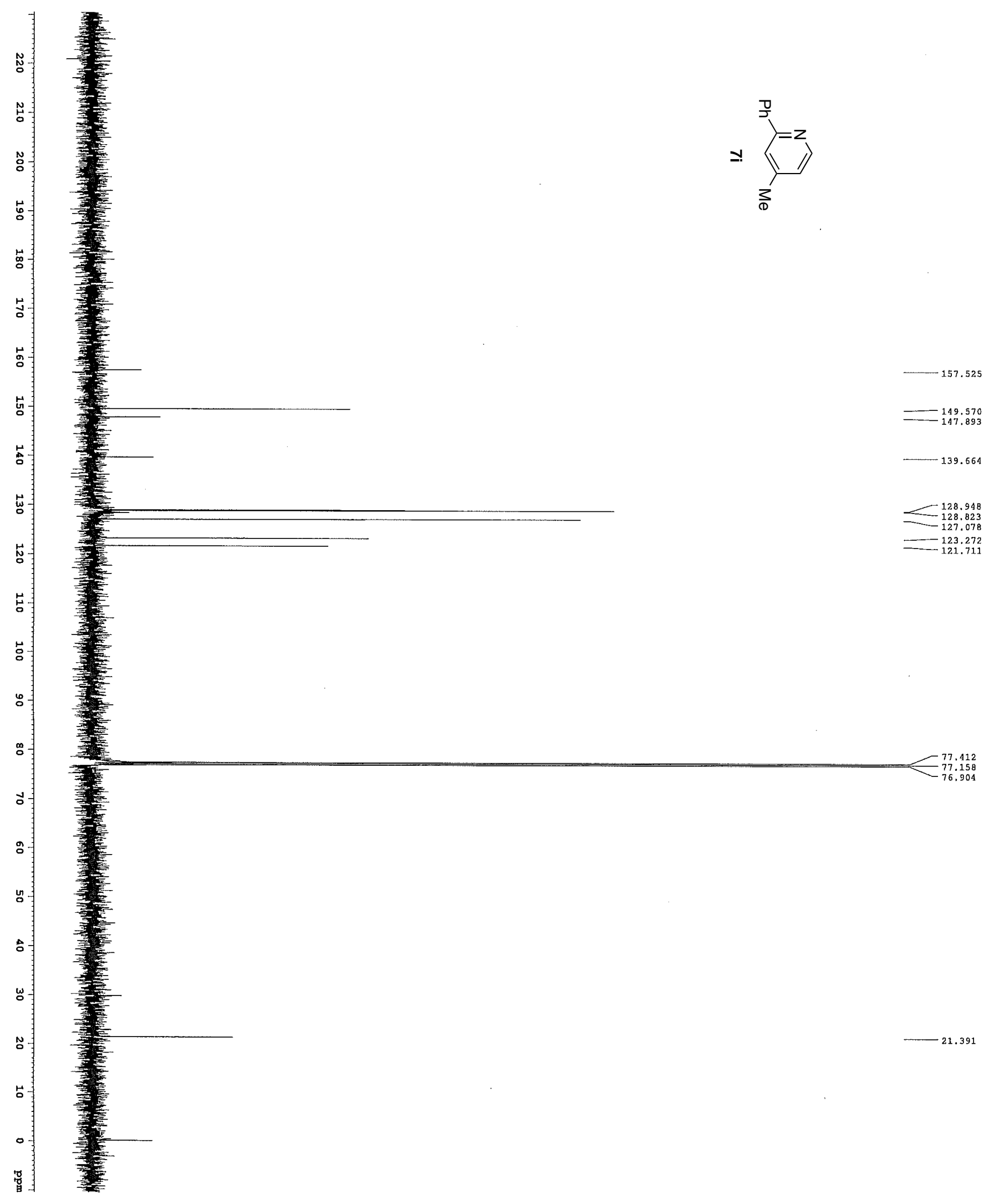



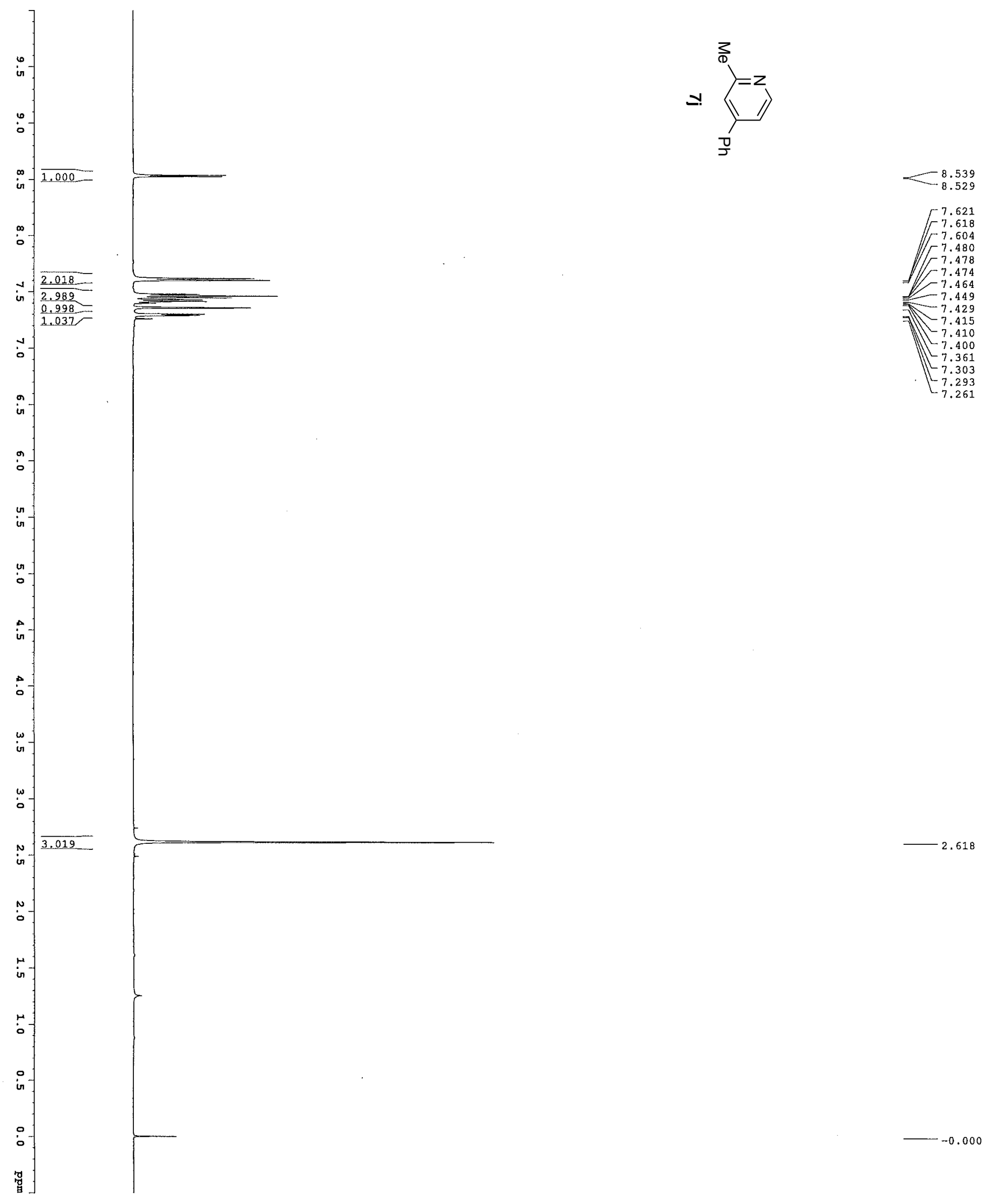


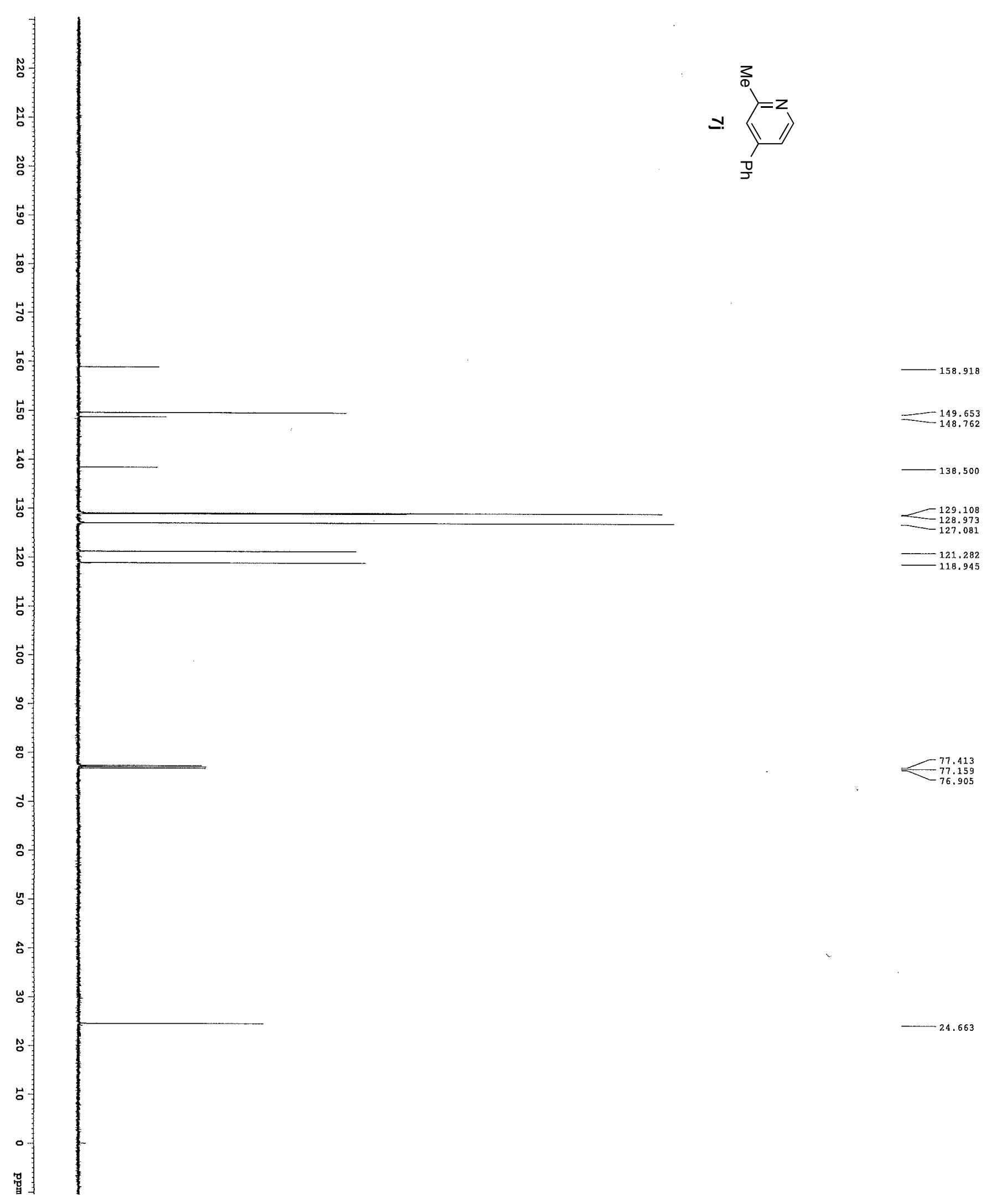



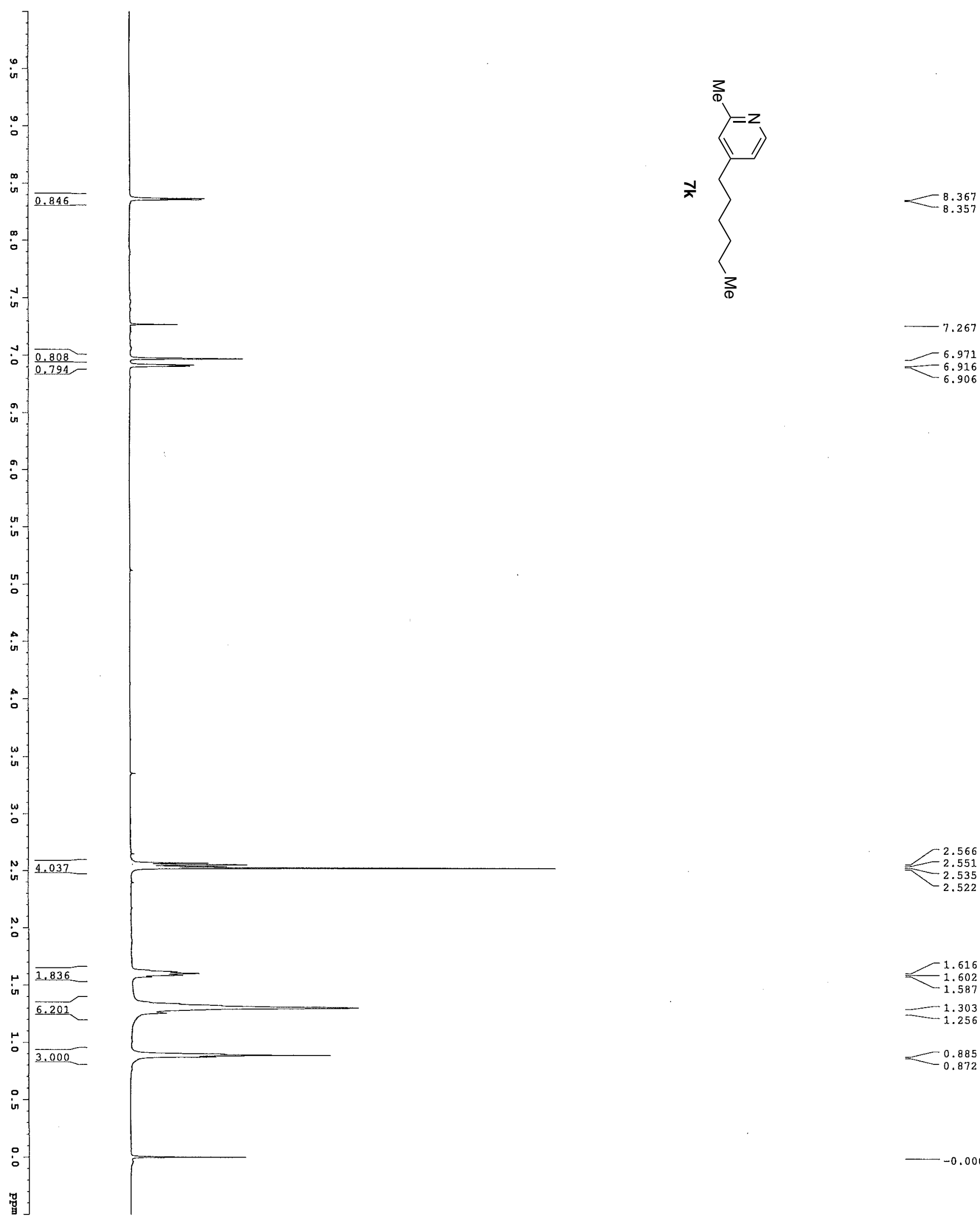

6.906

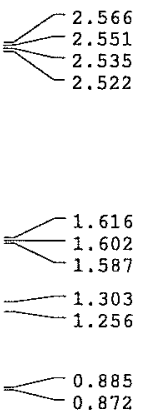



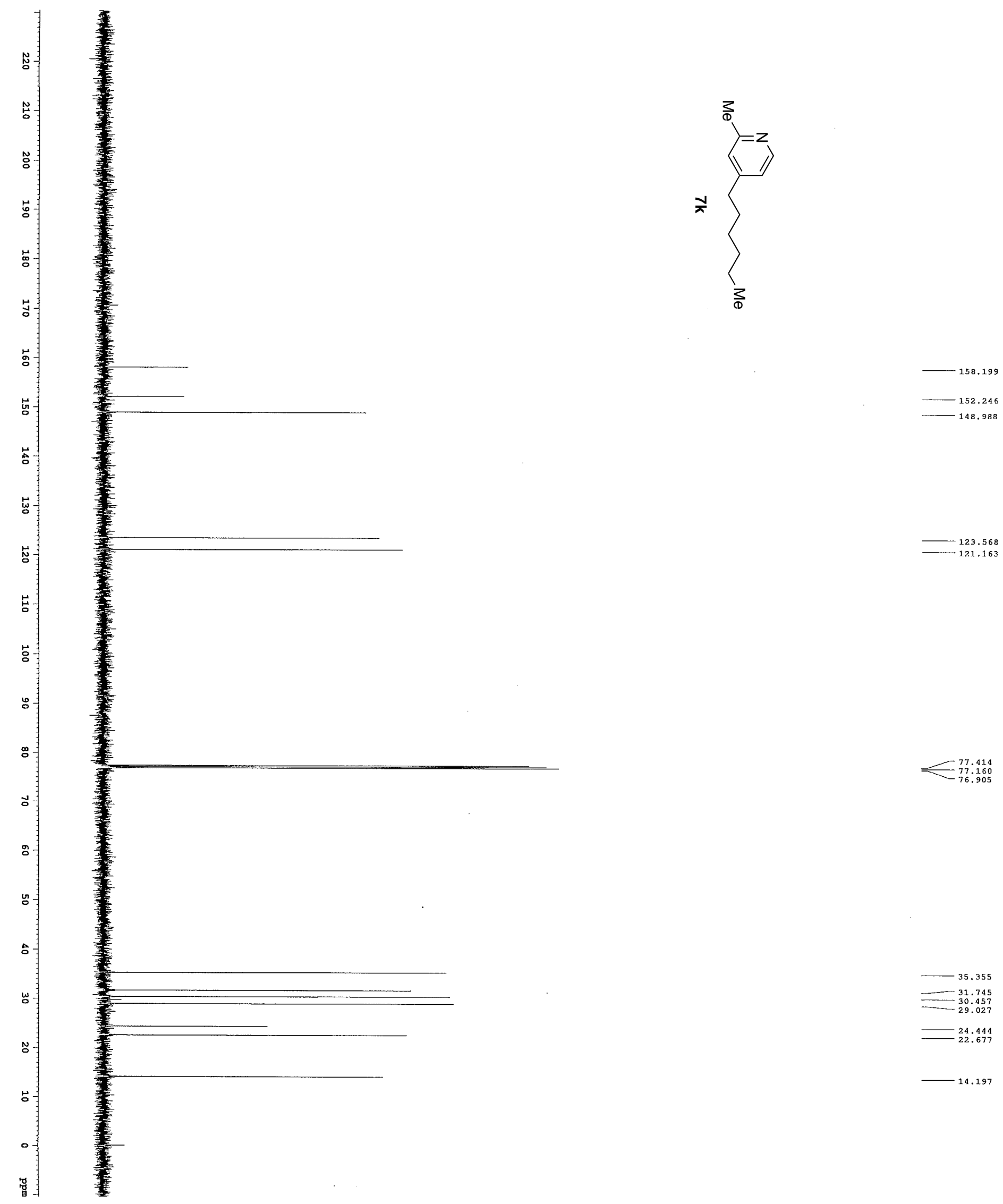

$-35.355$ $\begin{array}{r}31.745 \\ -30.457 \\ \hline \\ \hline\end{array} 29.027$ 24.444
22.677 

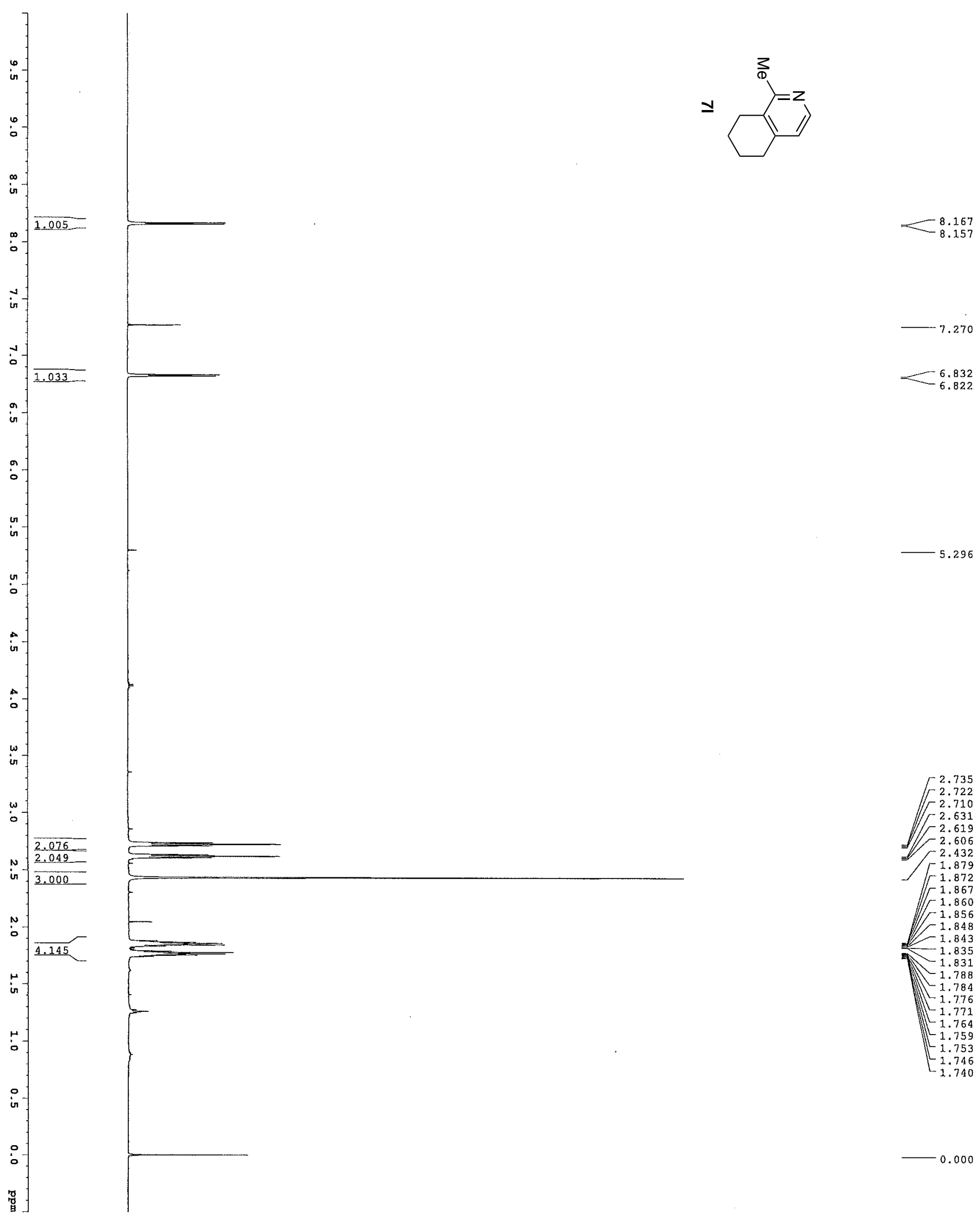

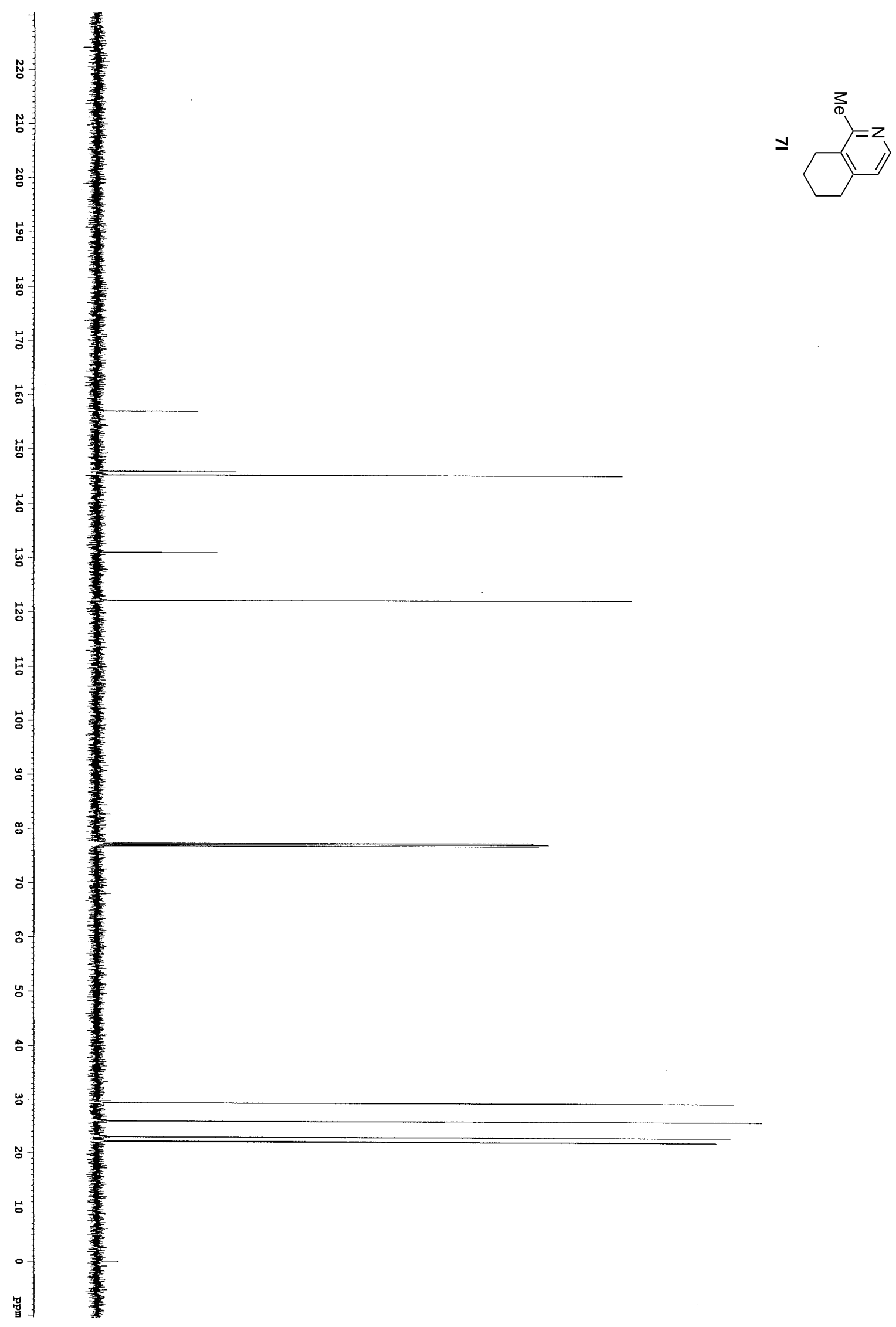

$-157.066$

$=-145.968$

$-131.000$

$-\square 122.210$
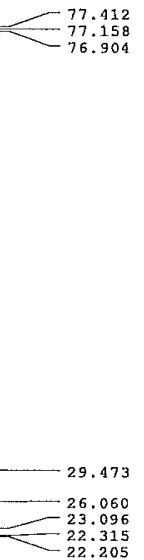


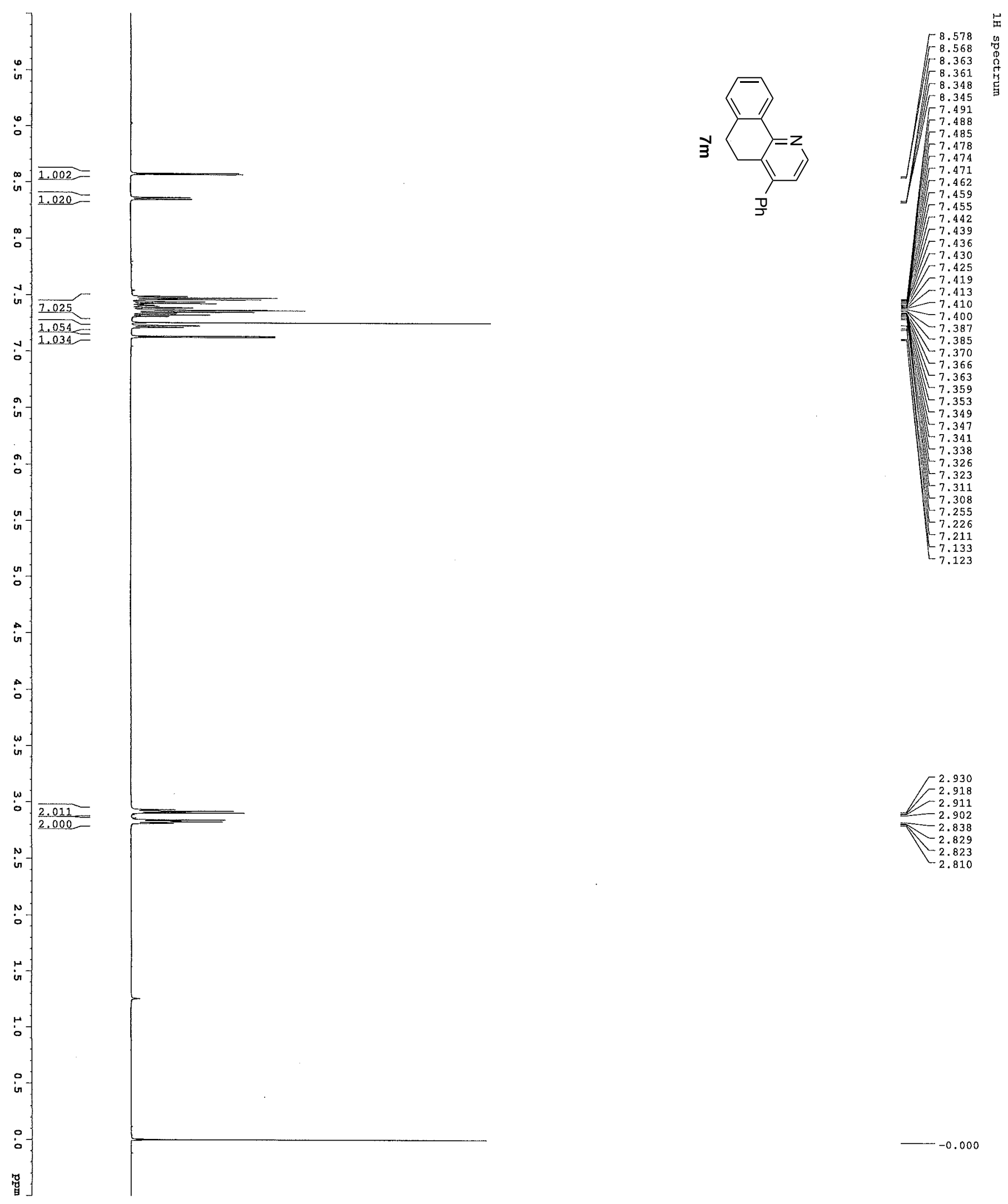



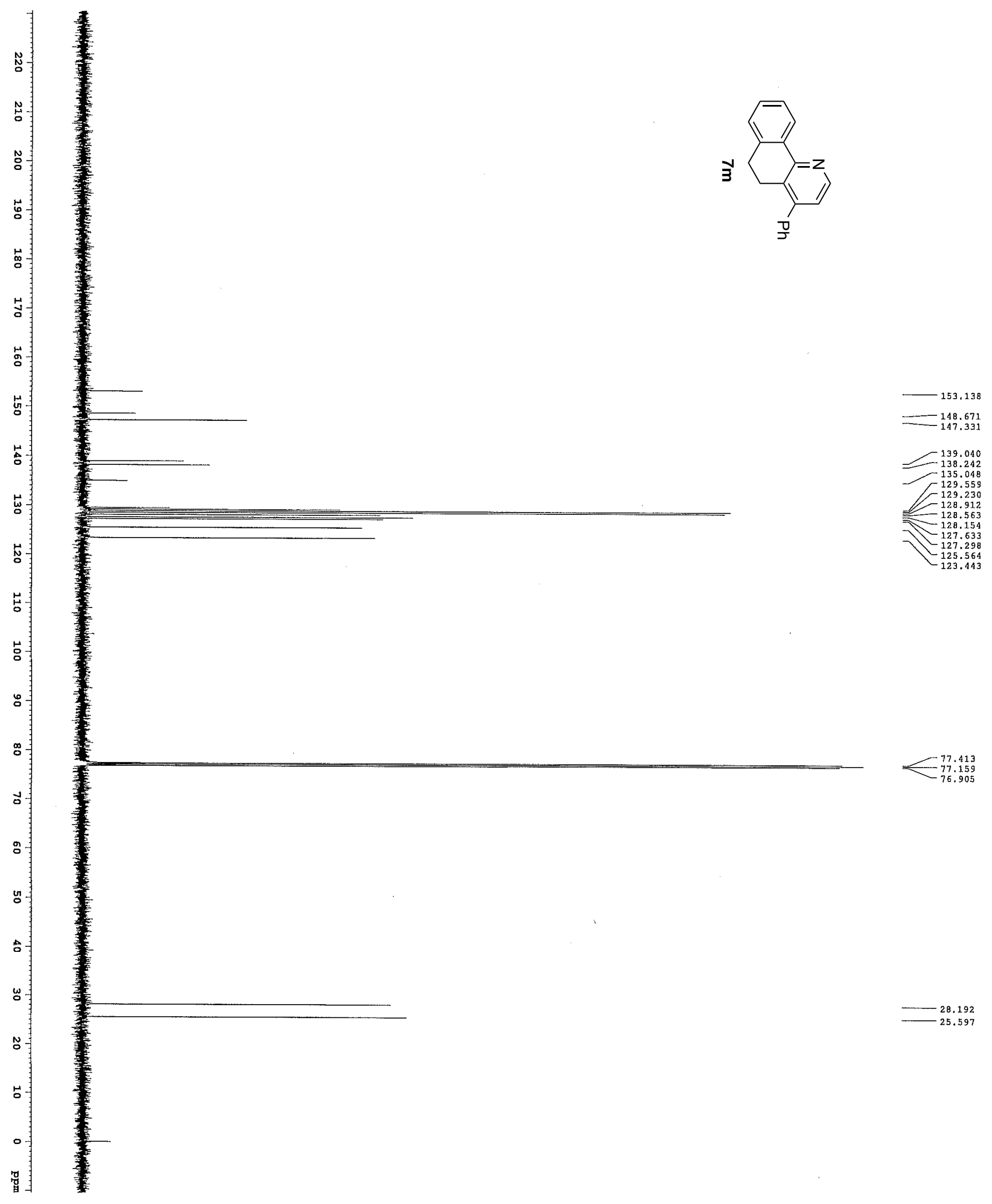

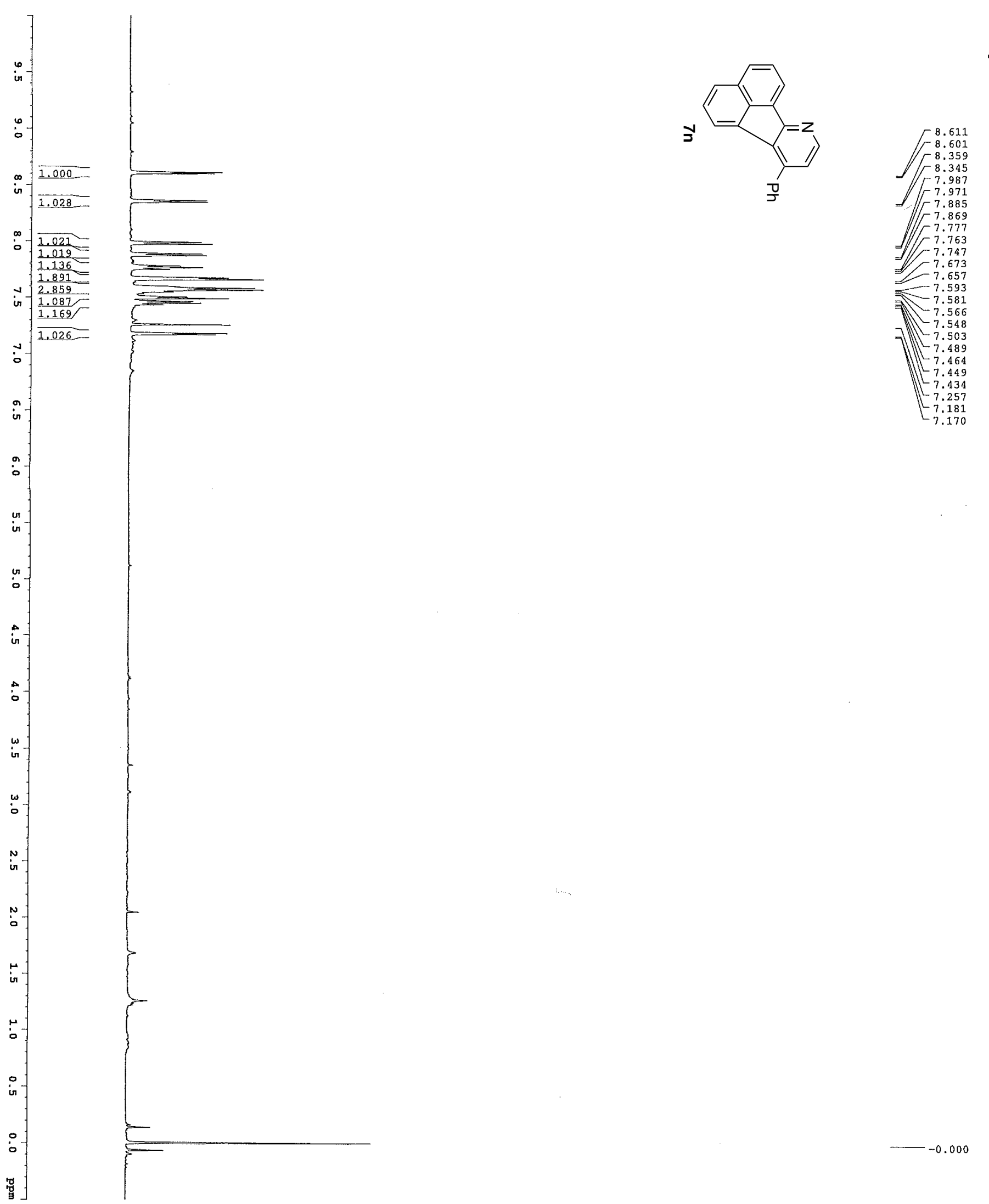

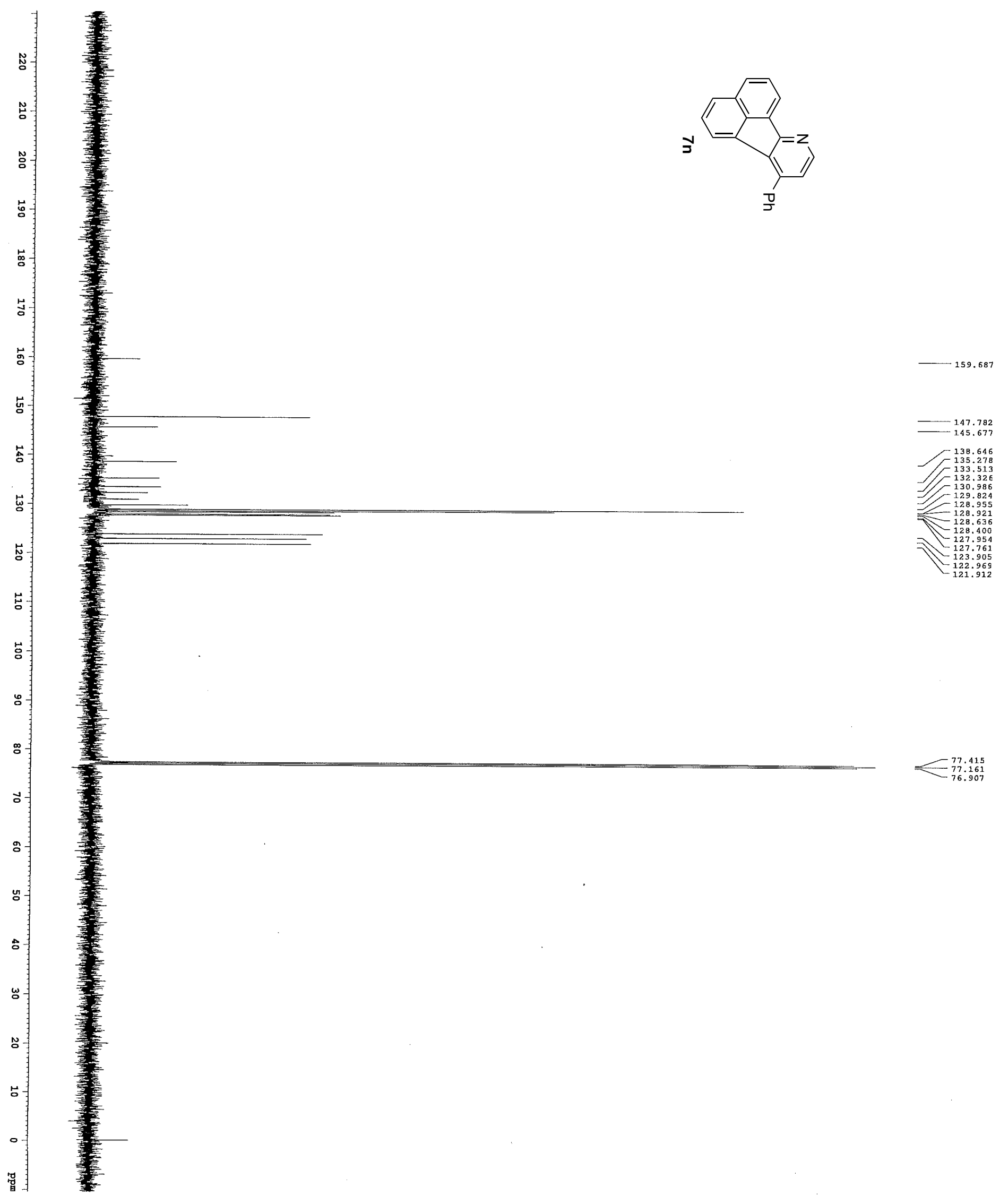


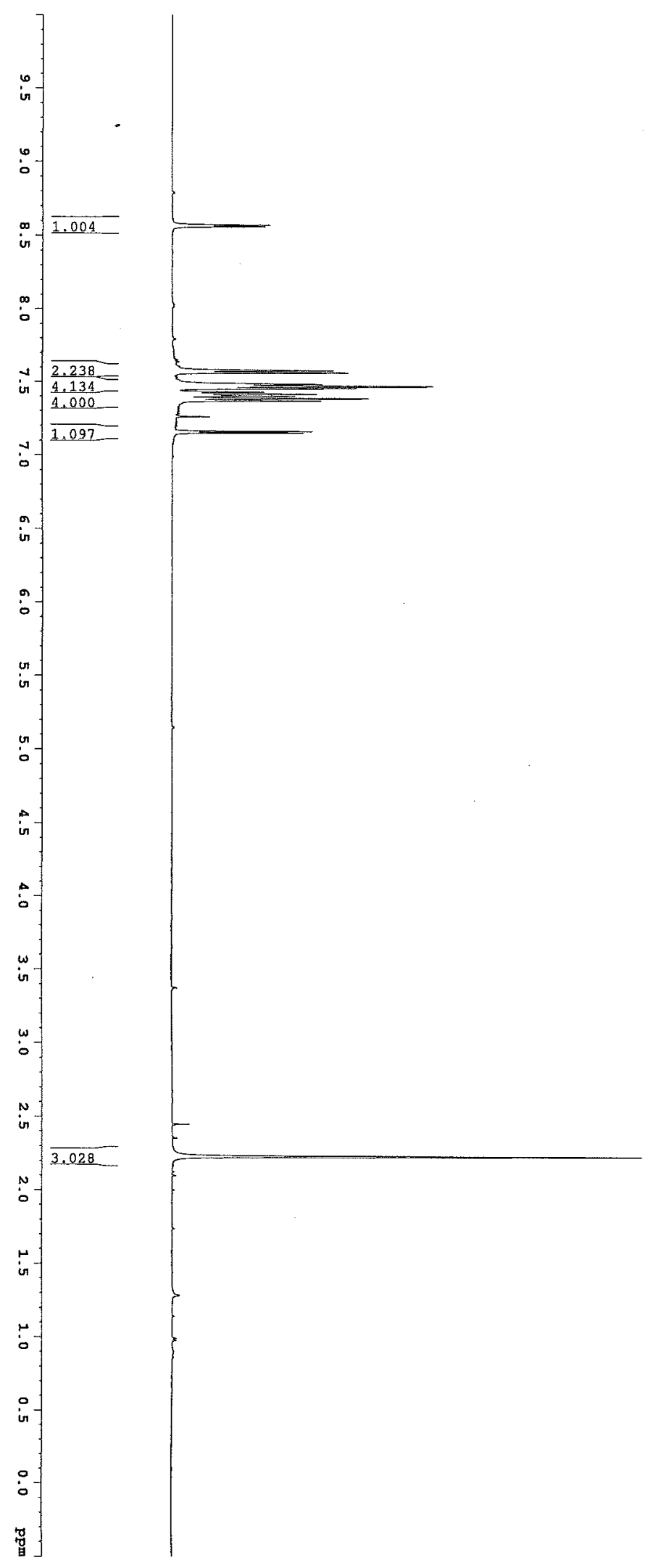



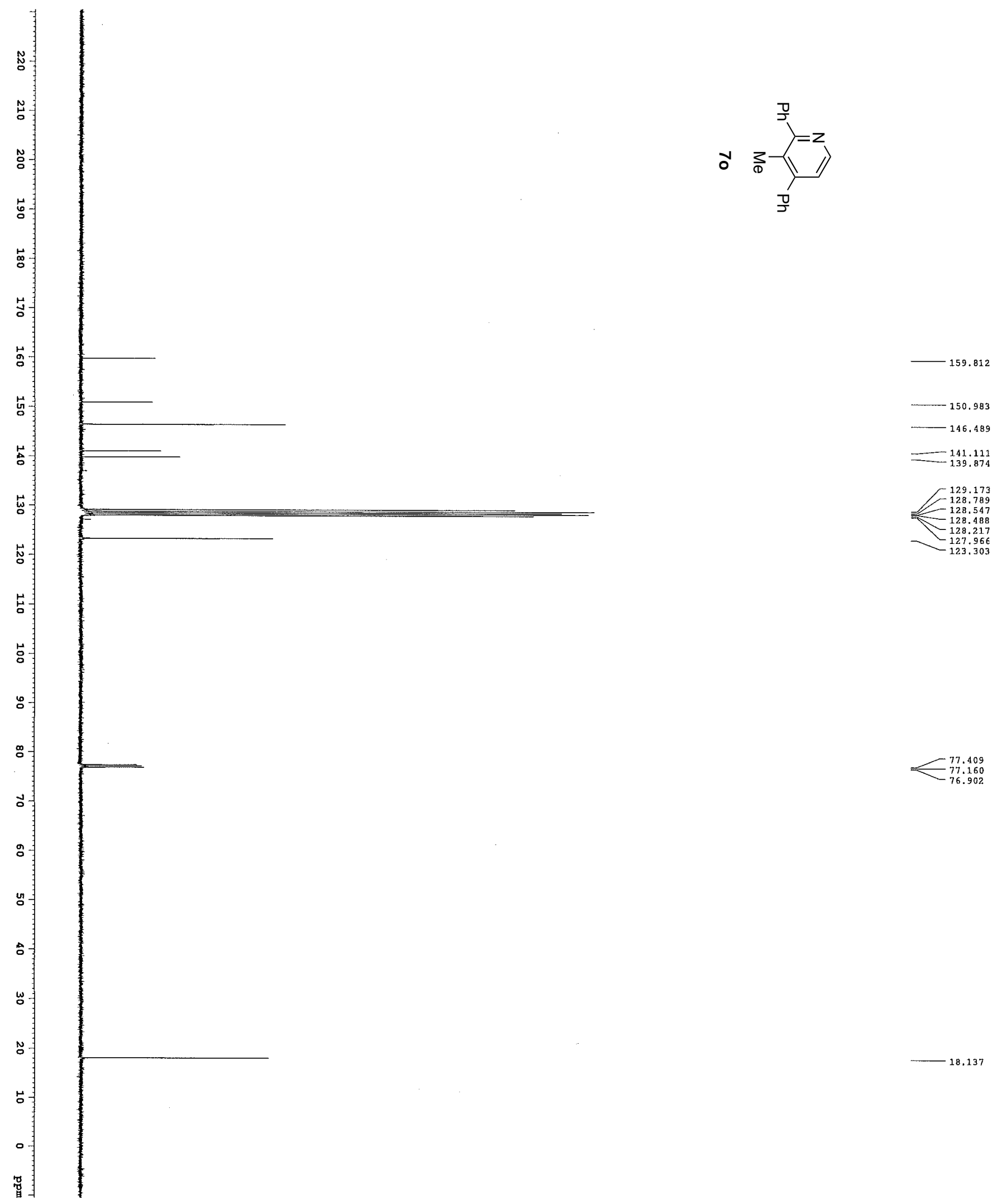
128.789
-128.547
-128.488 -128.547
-128.488
-128.217 $-127.966$

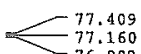



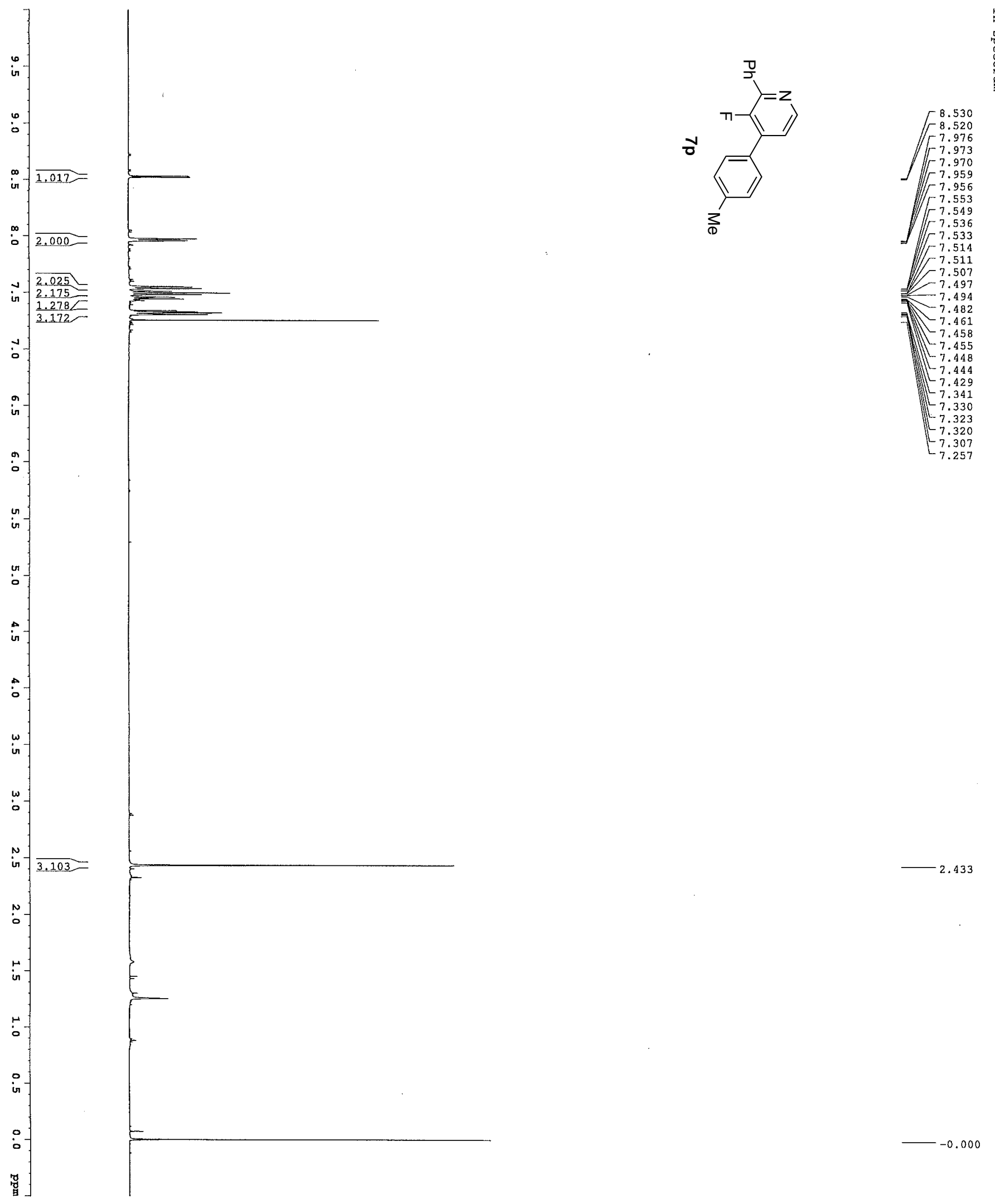

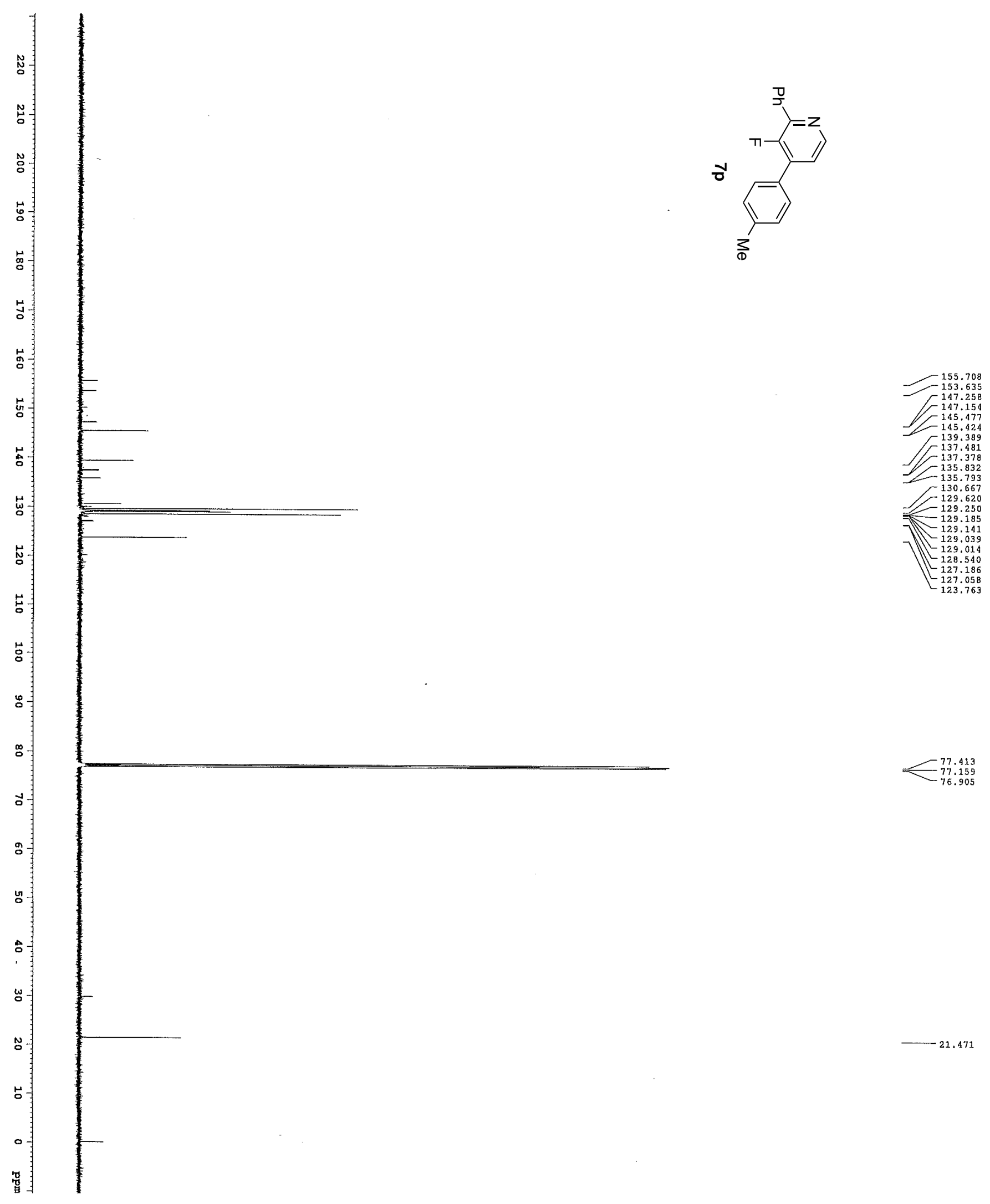


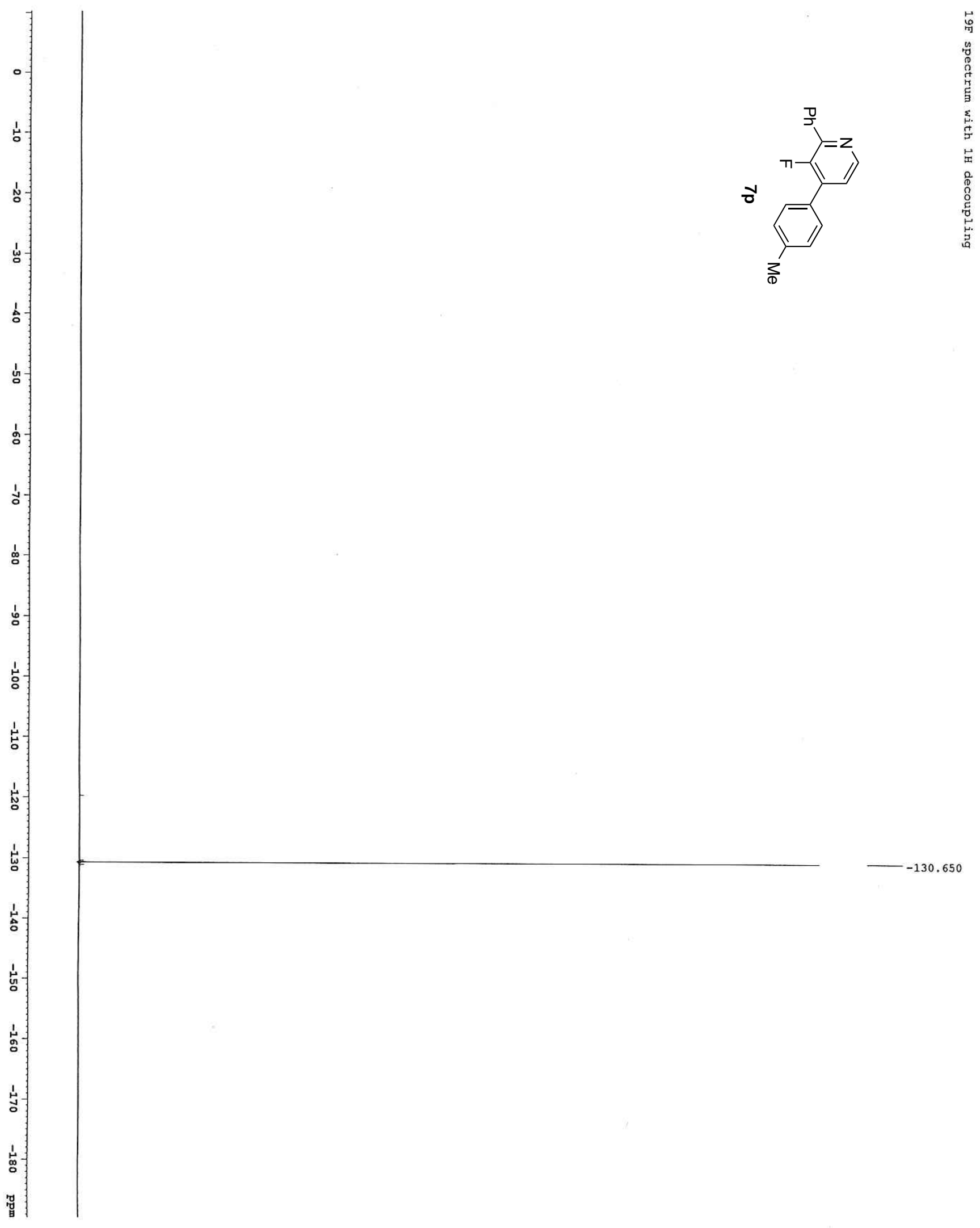




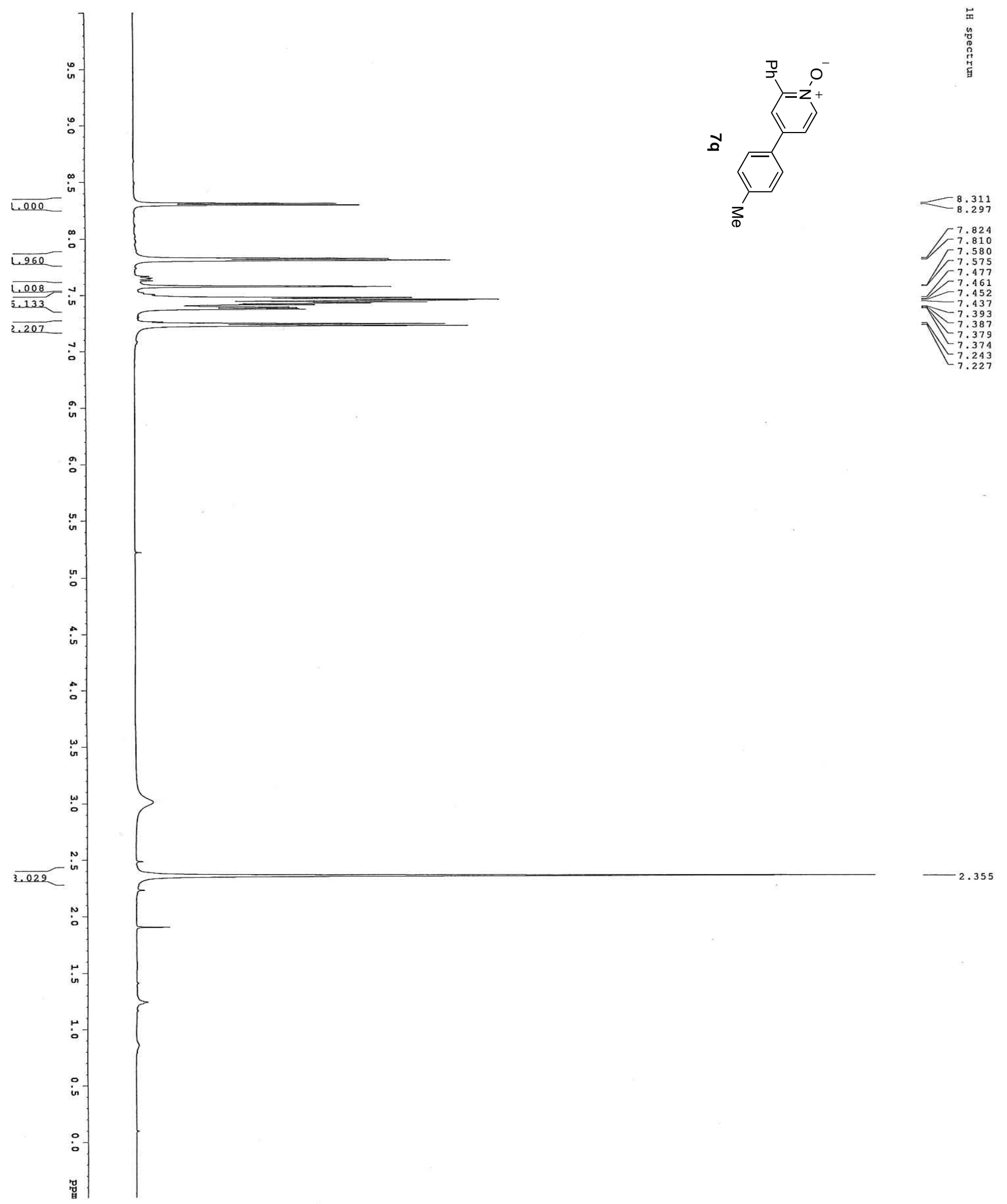




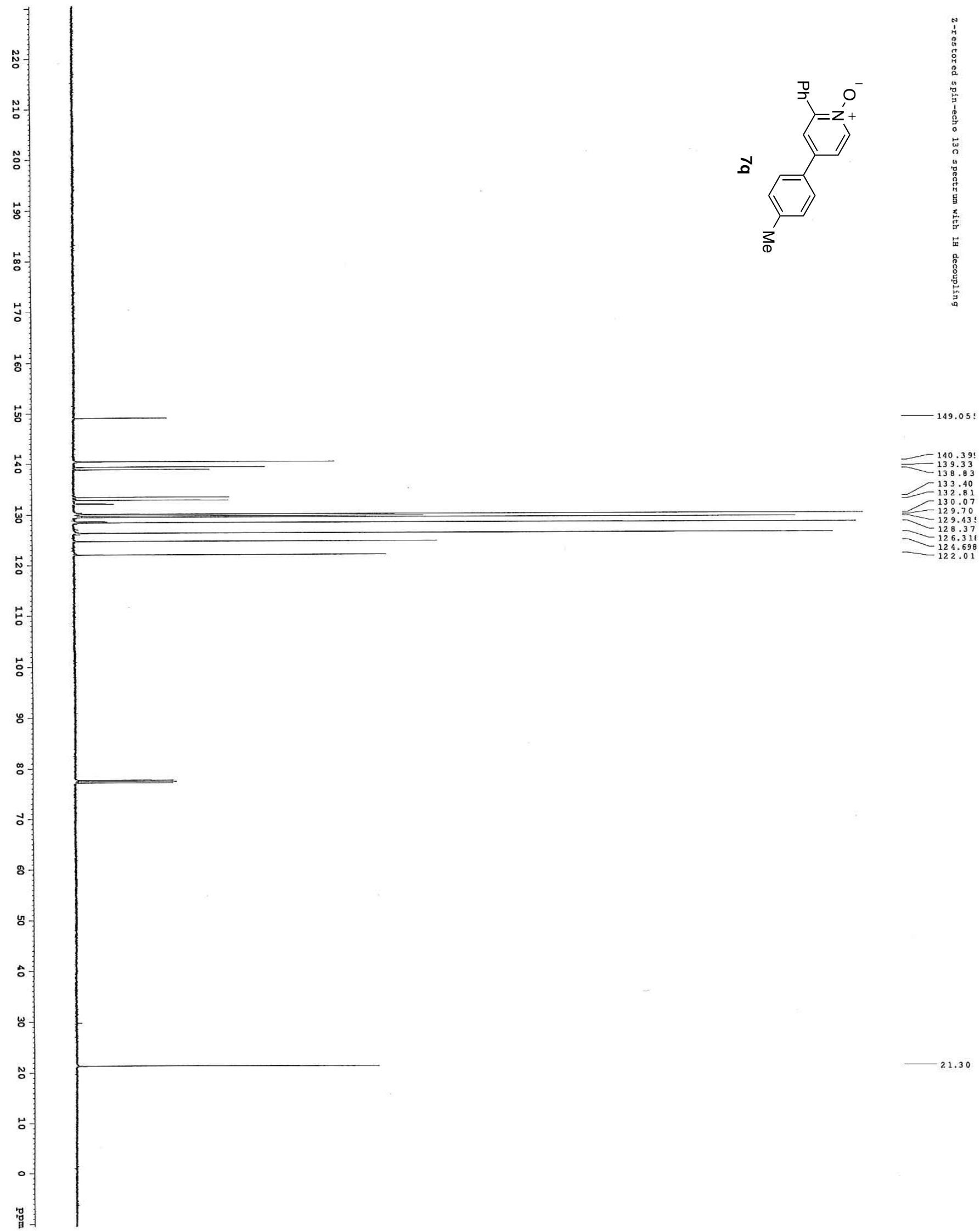




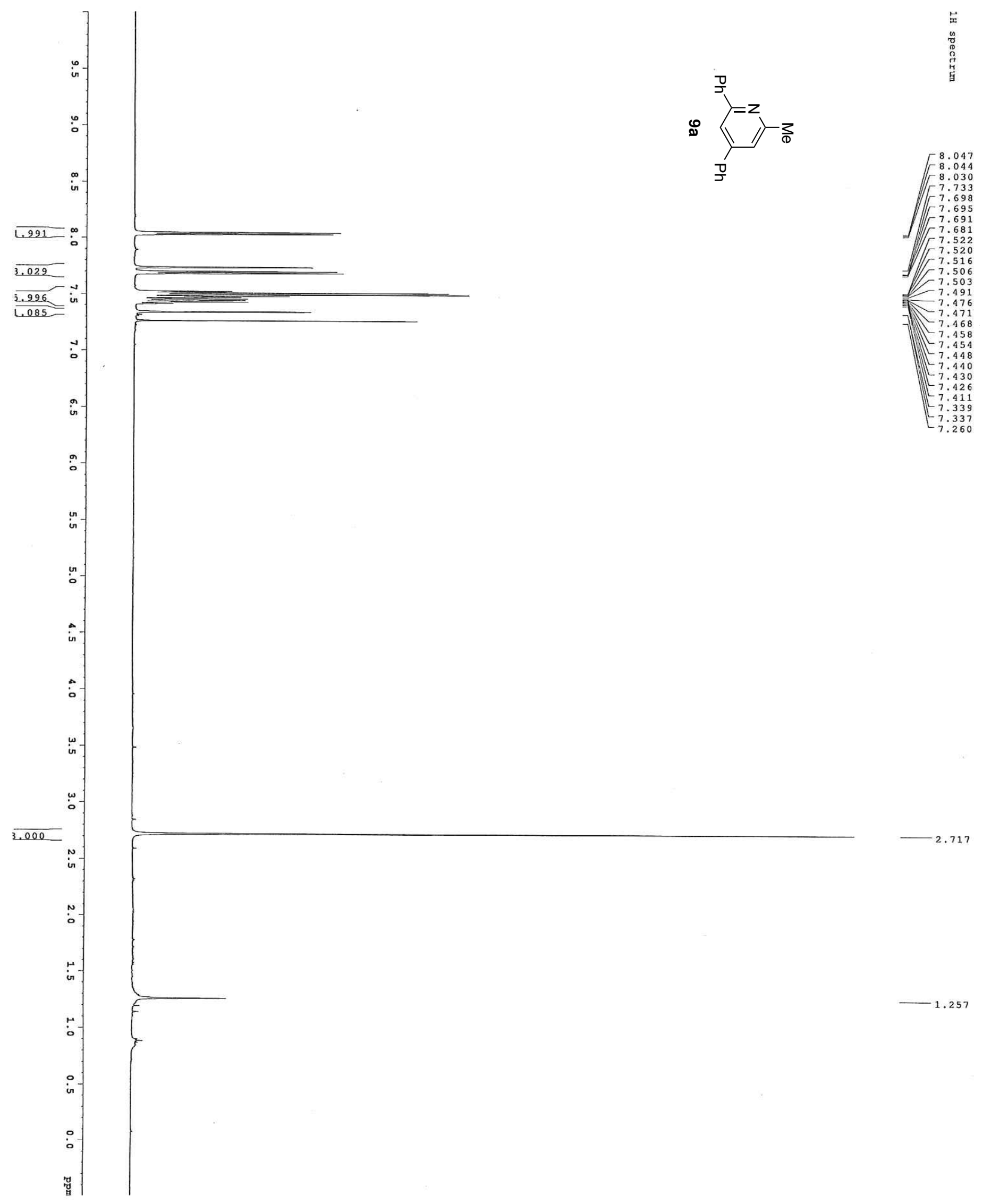




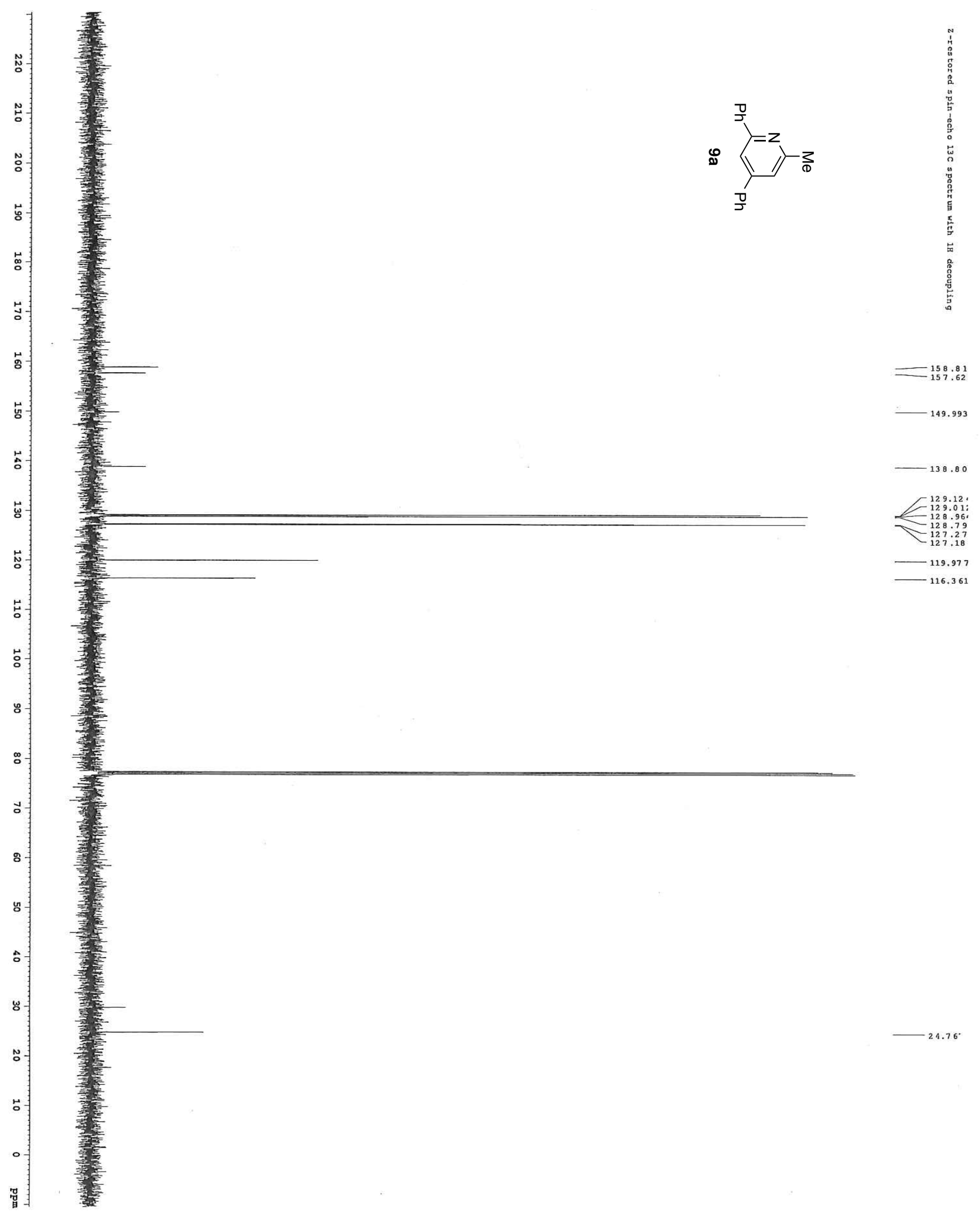



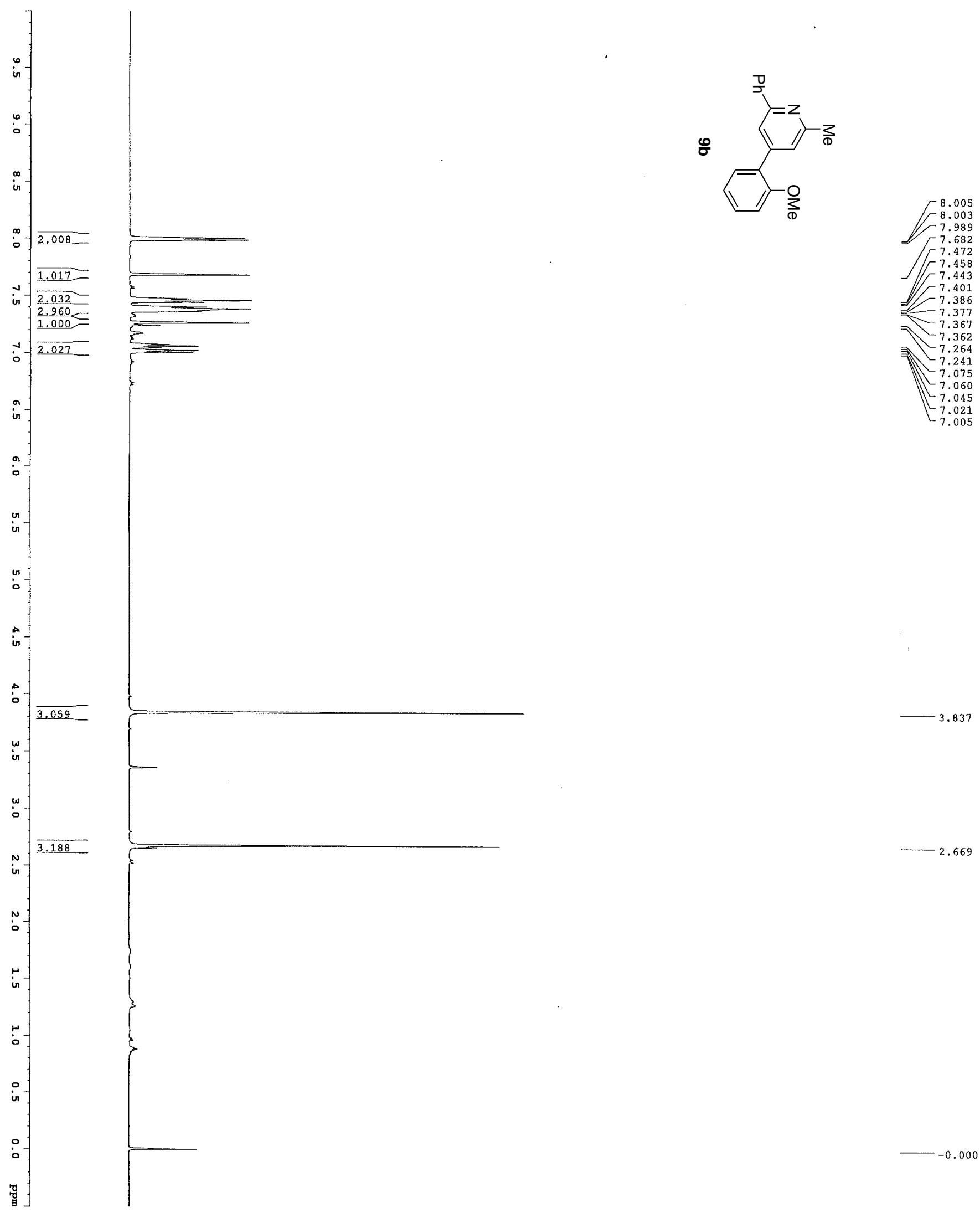

$-2.669$ 

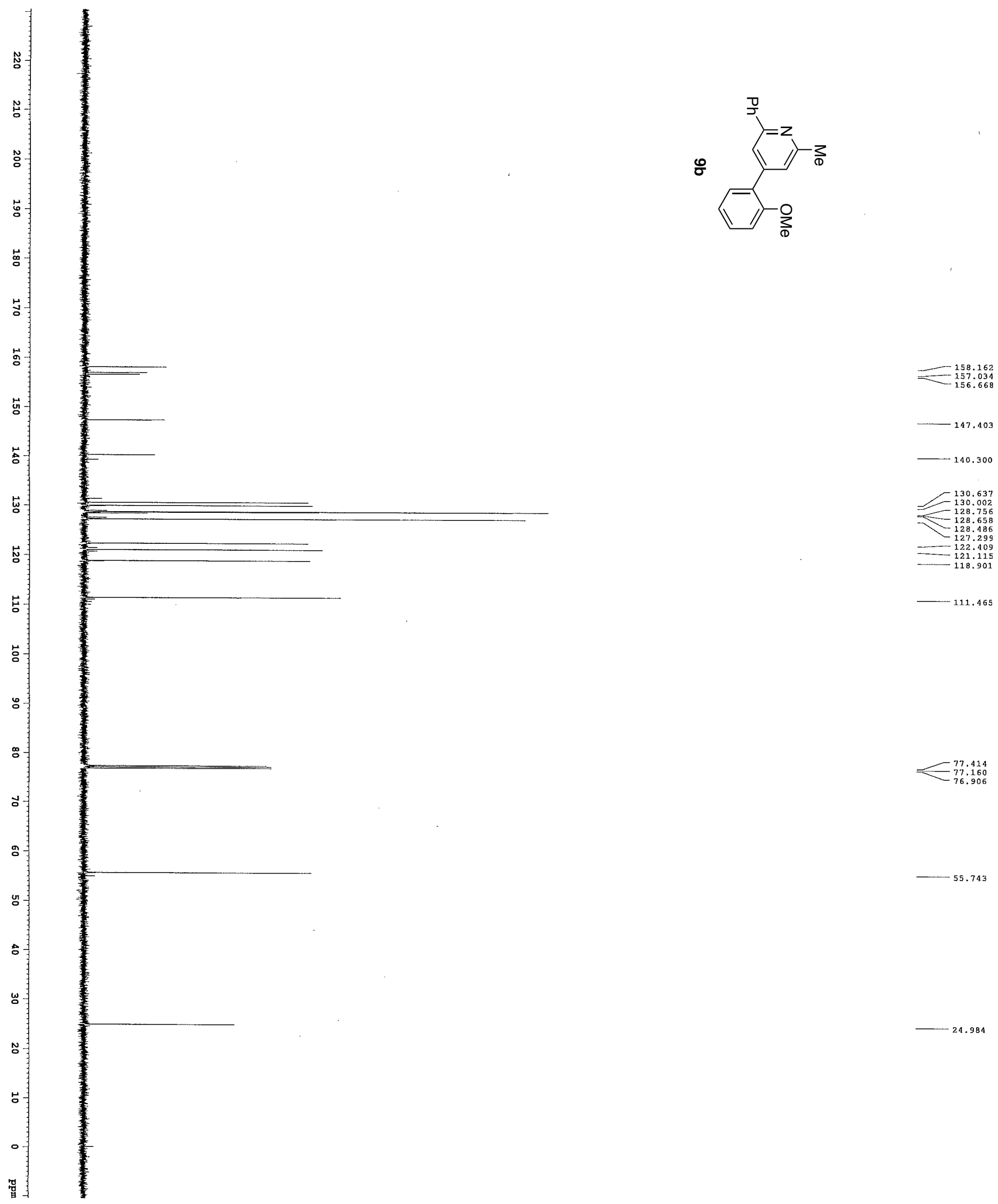


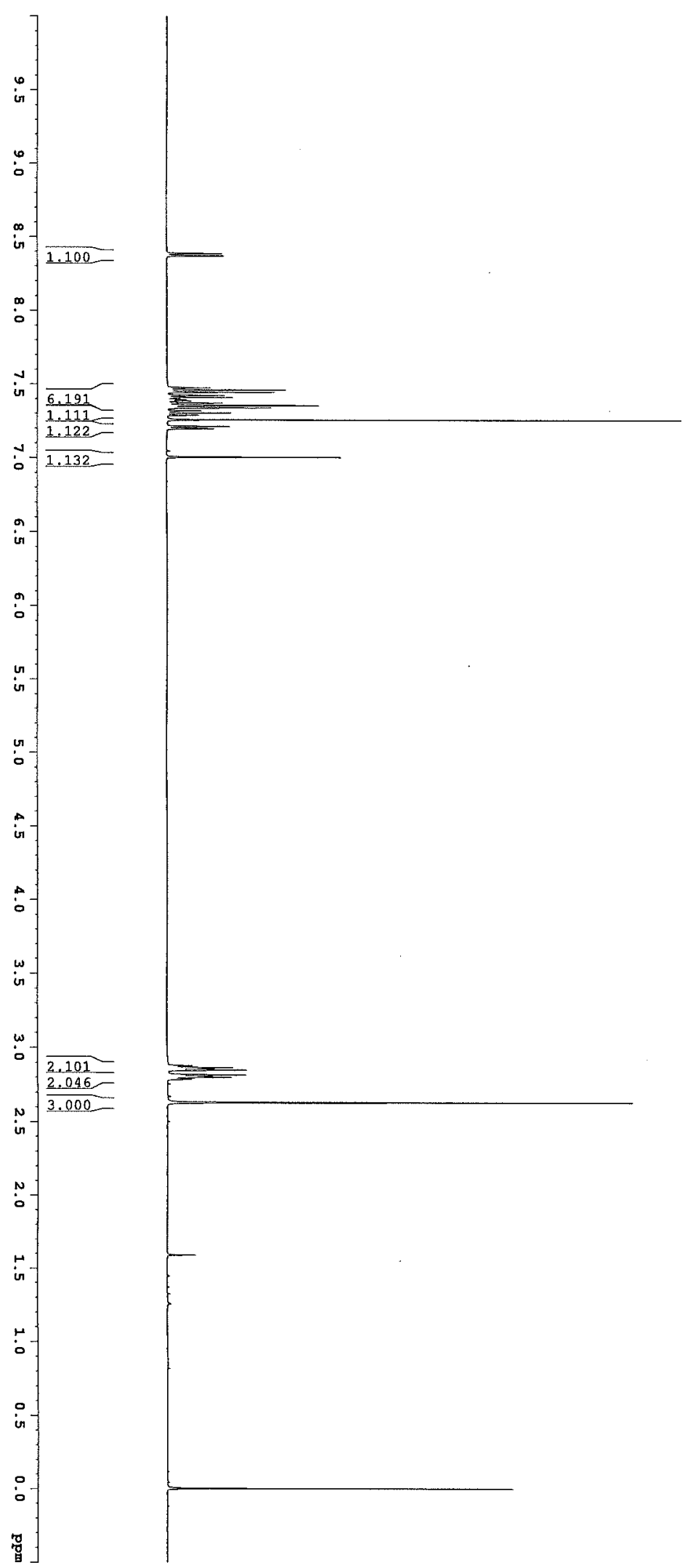<smiles>[CH]c1cc([Hg])c2c(c1)-c1ccccc1CC2</smiles>
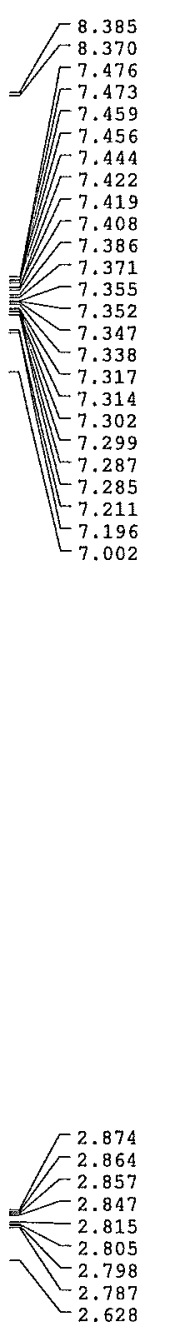


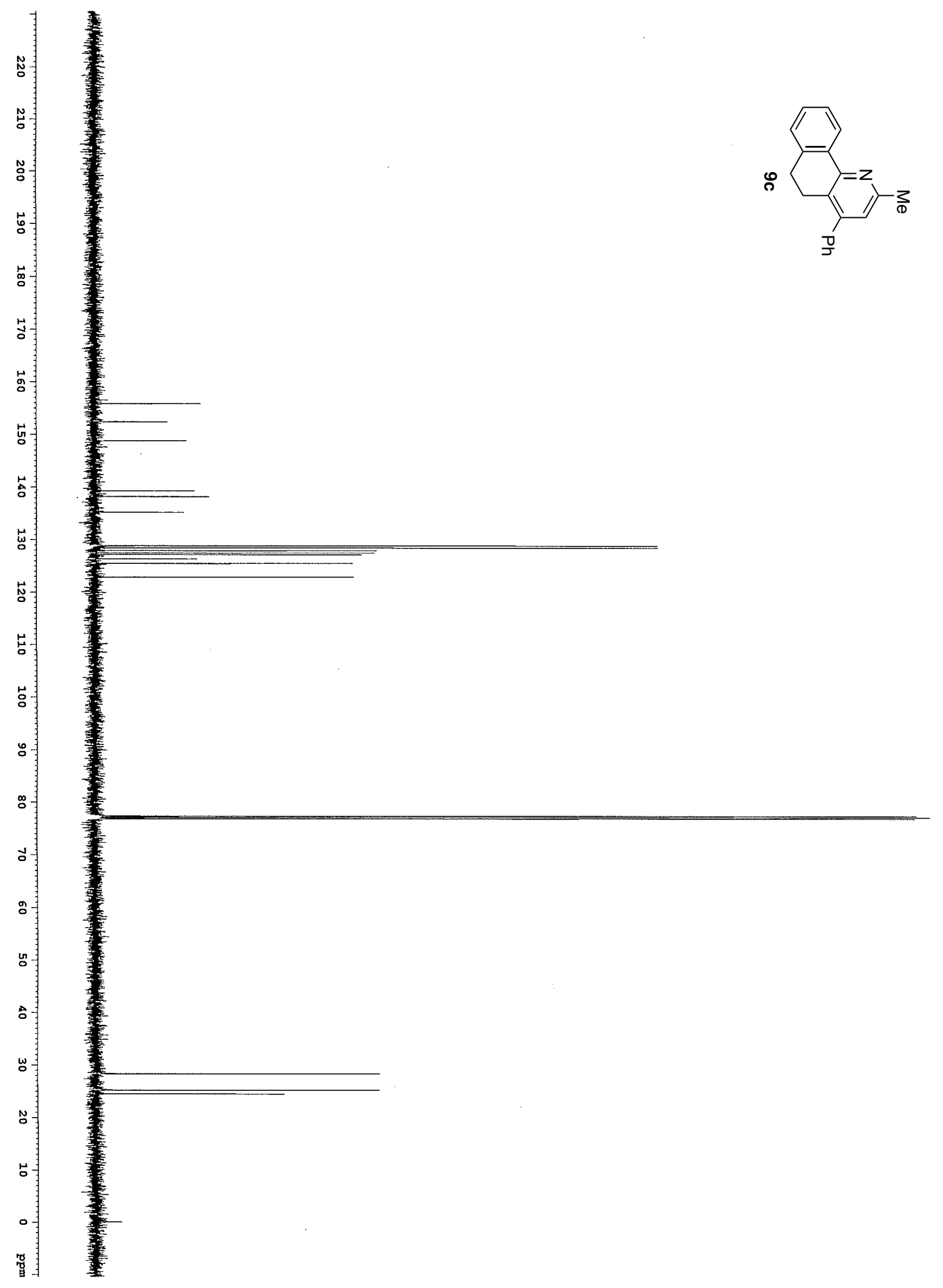



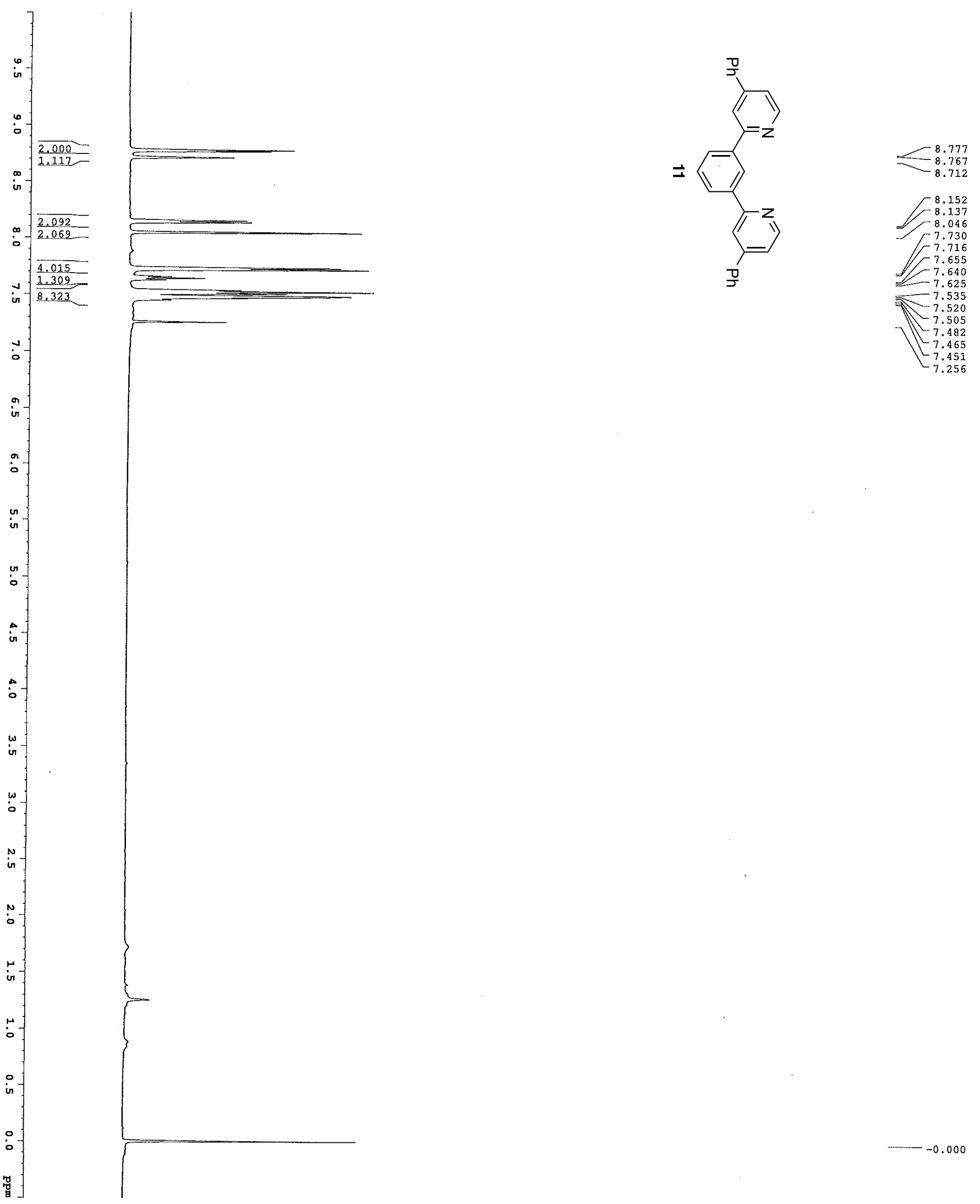

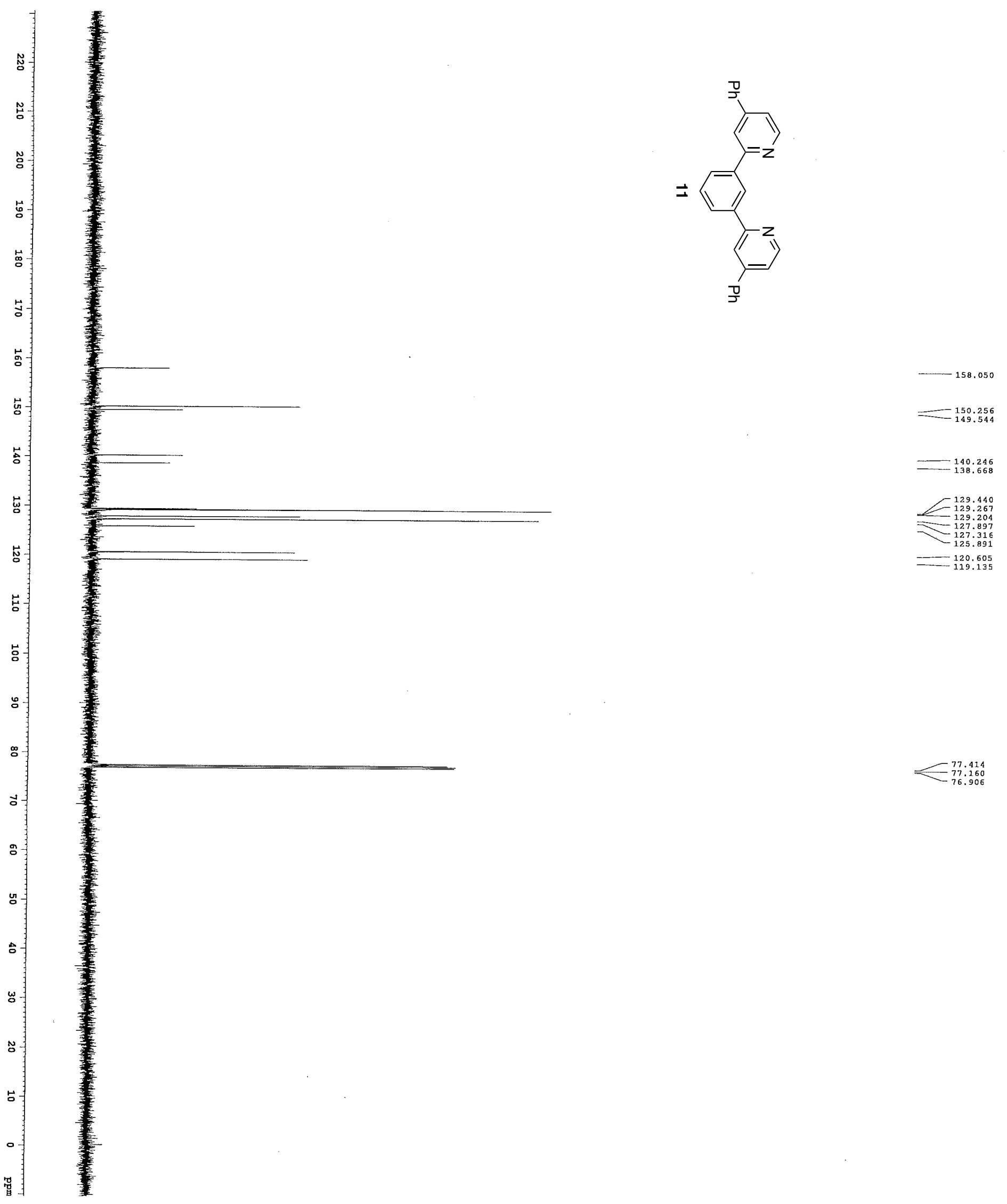

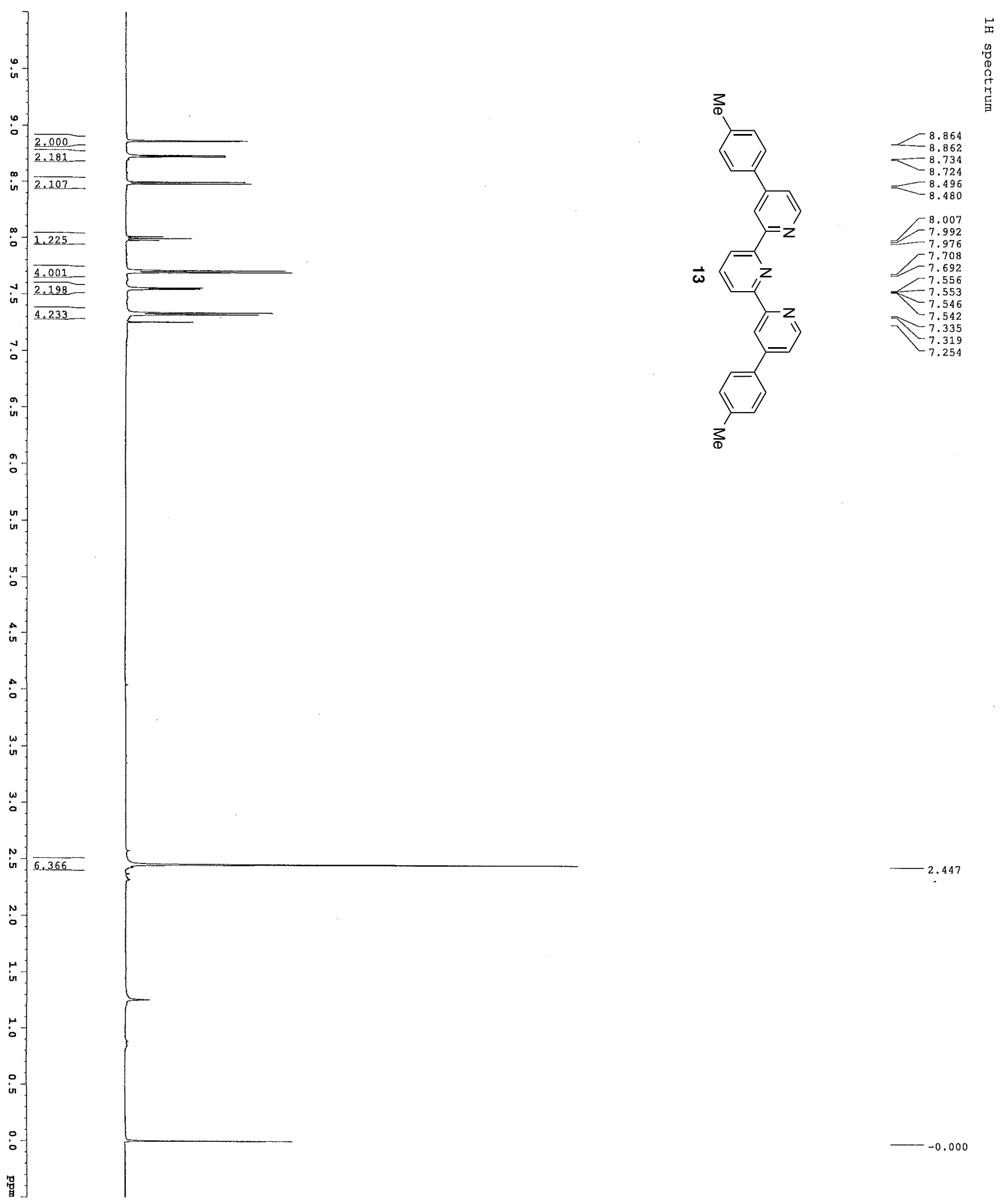

$\frac{4.001}{2.198}$

4.233

: (4)

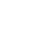

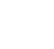

(n)

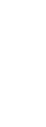




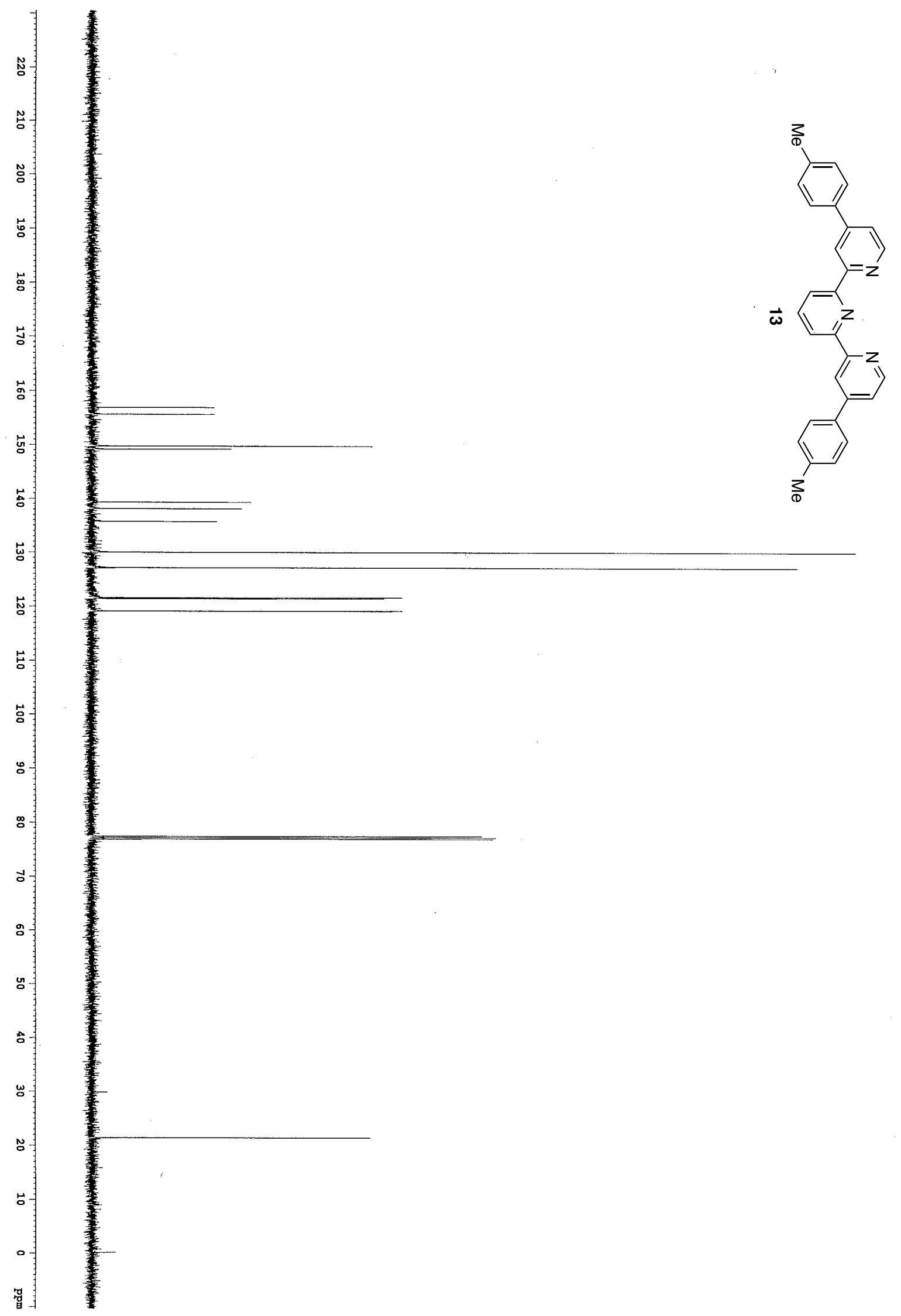

$=-156.884$ $=-\begin{array}{r}149.731 \\ 149.189\end{array}$

$\begin{array}{r}139.300 \\ -\quad 138.079 \\ \hline\end{array}$

$-129.970$

121.569
$\quad 121.402$

$<\begin{array}{r}77.413 \\ 77.159 \\ 76.905\end{array}$

$-21.434$ 